\title{
VINCZE GÁbOR
}

\section{Egy alföldi nagyközség a forradalom és megtorlás idöszakában}

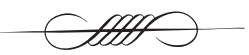

- A village of the Hungarian Plain in an era of Revolution and Reprisal -

AвSTRACt The demonstration on the 27th of October 1956. can be considered as the local beginning of the revolution on the municipality of Békés. That day the revolutionary comitee was elected and the local militia created. The revolution was peaceful and went down without atrocities. Even after the military defeat of the revolution on the 4th of November, the revolutionary comittee kept working for one and a half month. At the beginning of December 1956. one last recriminatory demonstration was organised, this was the last open event on the side of the revolution. On the eve of 1957. many people could not yet accept the defeat of the revolution. A few person kept on distributing fly-sheets, while others tried to continue armed organization. Reprisal arrived soon. In 1957. many revolutionarists received prison sentences longing from two to eight years.

KEywords 1956, Békés, revolution, reprisal

DOI 10.14232/belv.2017.2.1

https://doi.org/10.14232/belv.2017.2.1

Cikkre való hivatkozás / How to cite this article:

Vincze Gábor (2017): Egy alföldi nagyközség a forradalom és megtorlás időszakában. Belvedere Meridionale 29. évf. 2. sz. 5-26. pp

ISSN 1419-0222 (print)

ISSN 2064-5929 (online, pdf)

(Creative Commons) Nevezd meg! - Így add tovább! 4.0 (CC BY-SA 4.0)

(Creative Commons) Attribution-ShareAlike 4.0 International (CC BY-SA 4.0)

www.belvedere-meridionale.hu 


\section{Bevezetés}

Az 1956-os forradalom és szabadságharc nem előzménynélküli esemény volt, ugyanis a sztalinista-rákosista rendszerrel szemben országszerte, már a negyvenes évek óta folyt aktív küzdelem: Nyíregyházától Zalaegerszegig és Makótól Miskolcig az ország számtalan helyén jött létre ellenállási mozgalom. ${ }^{1}$

Békés megyében több szervezkedés, antikommunista ellenállási mozgalom létezett 1956 előtt. Erről így írtak egy 1957. november 13-i jelentésben: „1956. október előtt a megye legfertőzöttebb területe az orosházi, békési, szeghalmi, valamint a sarkadi járások voltak. A felsorolt helyeken az ellenséges tevékenység valamennyi fajtája megtalálható volt. 1950-55-ig a megyében több fegyveres szervezkedés lett felszámolva. A felszámolt szervezkedések közül említésre méltó az Orosháza és környékén felszámolt »Fehér Gárda« szervezkedés, a Szeghalom és Füzesgyarmat környékén felszámolt »Sárréti Sasok«, Békéscsaba, Sarkad, valamint Mezőberény területére kiterjedő ellenállók szervezkedése, valamint a békéssámsoni »Magyar Ellenállási Mozgalom « $₫ 2$ elnevezésű röpcédulás csoport.”3

A fenti jelentésben említett Fehér Gárda területileg nagyjából a Hódmezővásárhely-Orosháza-Makó-Szentes négyszögben működött. 1949 nyarán kezdték szervezni, de egy évvel később megtörtént a mozgalom egy részének „felgöngyölítése”. Az első Fehér Gárda-perben, 1951. január 13-án harminc fehérgárdistát állítottak a szegedi megyei bíróság elé. Az első és másodrendű vádlottat (Blahó Jánost és Kovács Istvánt) halálra ítélték, és a Csillagbörtönben kivégezték, az egyik letartóztatott személyt azonban bírósági ítélet nélkül „likvidálták” - vagyis valószínüleg halálra kínozták, amit utólag öngyilkossággal álcáztak. ${ }^{4}$ A mozgalmat ezzel nem sikerült megsemmisíteni, a szervezkedés tovább folyt, végül csak négy évvel később számolták fel végérvényesen.

A másik említett ellenállási mozgalom, a „Sárréti Sasok” Szeghalom-Füzesgyarmat-Püspökladány térségében fejtette ki tevékenységet, és több kisebb csoport egyesülésével jött létre. Történetüket Öze Sándor dolgozta fel, aki egyes korabeli ávós iratokra hivatkozva azt állította, hogy ebben a mozgalomban Békés is érintett. ${ }^{5} \mathrm{Ez}$ azonban tévedés, ugyanis ezt semmilyen más levéltári forrás sem támasztja alá.

A jelentésben harmadszorra említett, „Békéscsaba, Sarkad, valamint Mezőberény területére kiterjedő ellenállók szervezkedése" a békéscsabai Puskás József nevével fémjelzett mozgalom volt. Ennek a szervezkedésnek a feltárása még csak most kezdődött el. Egyelőre annyi tudható, hogy a „népi demokratikus államrend megdöntésére szervezkedés kezdeményezésével és vezetésével” valamint fegyverrejtegetéssel megvádolt Puskás József és huszonegy társa ellen 1953. május 23án a gyulai megyei bíróság hozott ítéletet. Puskást tizenöt évre ítélték. ${ }^{6}$

\footnotetext{
${ }^{1}$ Az Állambiztonsági Szolgálatok Történeti Levéltárában (ÁBTL) jelenleg huszonhárom szervezkedésnek található meg a vizsgálati és/vagy az operatív dossziéja. (Összesen több mint százhetven dosszié, mintegy kétszázezer oldalnyi irat.)

2 Lásd Domonkos, 1990. és Orgoványi, 2013.

3 A BM Békésmegyei Rendőrfőkapitányság Politikai Nyomozó Osztály 203-6/153. sz. „Szigorúan titkos!” jelzésű jelentése a „belsőreakció tevékenységéről”. Magyar Nemzeti Levéltár Békés Megyei Levéltára (MNL BML), Békési Fióklevéltár, MSZMP-archívum, 1. fond, 14. fondcsoport, 9. őrzési egység, 33-38.

4 Bővebben Vincze 2016a.

5 ÖZE - ŐZE 2012. 60., 67-69.

${ }^{6}$ MNL BML, a Békés Megyei Bíróság titkos ügykezelésű iratai, XXV.10b fond, 3. doboz, B.001/1953.
} 
A fenti három szervezkedésben ugyan békésiek nem vettek részt, ez azonban nem jelenti azt, hogy az akkori ${ }^{7}$ nagyközségben ne ütötte volna fel a fejét tömeges elégedetlenség: egy ávós jelentés szerint 1951-ben népes tömeg tüntetett a tagosítás miatt, amelyet széleskörủ letartóztatás követett. ${ }^{8}$ Két évvel később, 1953-ban a megye más településein, így például Dévaványán és Kondoroson is volt tömegtüntetés a sztalinista paraszt-politika miatt.

Mivel Békés alapvetően agrártelepülés volt, a Magyar Dolgozók Pártja (MDP) parasztellenes politikája érintette legsúlyosabban. Amikor 1948. augusztus 20 -án Kecskeméten Rákosi Mátyás meghirdette „a mezőgazdaság szocialista átalakításának” programját, elkezdődött az erőszakos „kollektivizálás”, más kifejezéssel élve a kolhozosítás. A sztalinista politika célkeresztjébe a „kuláknak" nyilvánított gazdák kerültek. A pénz- és terményadó, a kötelező beszolgáltatások milliókat tettek nincstelenné. Aki nem tudta teljesíteni a teljesíthetetlen beszolgáltatási kötelezettséget, az előtt két út állt: vagy „önként” fölajánlja a földjét az államnak, remélve, hogy ezek után nem nyomorgatják tovább, hanem leveszik a „kuláklistáról” (nem biztos, hogy ezt megtették!) vagy belépett a gyűlölt kolhozba (szovjet típusú mezőgazdasági termelőszövetkezetbe) a földjével, állatállományával és teljes mezőgazdasági fölszerelésével együtt. ${ }^{9}$

A „kulákosításon” kívül volt még egy módszer, amellyel az önálló gazdálkodáshoz ragaszkodó parasztokat megfoszthatták az őseiktől megörökölt, vagy hosszú évek gürcölésével megszerzett földjeiktől: a tagosítás. Akinek ugyanis a földjét betagosították a rajta lévő tanyával együtt, vagyis tulajdonképpen egyszerüen kisajátították, kapott ugyan hasonló méretü földbirtokot, de jóval rosszabb minőségüt vagy olyan távoli helyen fekvő területet, amelynek megművelése nem volt kifizetődő, a rajta lévő tanya pedig jóval szegényesebb volt, mint amit elvettek.

Békésen a gazdák egy részének, mintegy hetven személynek a legnagyobb sérelme az volt, hogy a Békési Tangazdaságot a „betagosított” földjeikkel hozták létre. A forradalom napjaiban, sőt, még november 4. után is az egyik leggyakrabban hangoztatott követelés a tangazdaság felszámolása és a korábban kisajátított földek visszajuttatása volt eredeti tulajdonosaiknak.

Az erőszakos kolhozosítás Sztálin halálát követően - átmenetileg - szünetelt. A moszkvai pártvezetés által miniszterelnöknek megtett Nagy Imre ugyanis, a híressé vált júliusi kormányprogramjában - szovjet gazdáinak utasítására ${ }^{10}$ - lehetővé tette, hogy azok, akik csak kényszer hatására léptek be a kolhozba, a bevitt földjükkel, felszerelésükkel együtt kiléphessenek, és önállóan gazdálkodhassanak tovább. Ennek hatására az egész országban, így Békésen is a szövetkezetek nagy része felbomlott. Bár Nagy Imre 1955. tavaszi bukása után Rákosi Mátyás és köre tovább erőltette a „szövetkezetesítést”, a magángazdák többségét nem sikerült bekényszeríteni a kolhozba.

\section{A forradalom első napja Békésen}

A fővárosi antisztalinista forradalom október 23-i, keddi kitöréséről megbízható hírek vidékre lassan jutottak el. A Szabad Európa Rádió és az Amerika Hangja magyar nyelvű adásaiból - már akik fogni tudták ezeket a készülékükön - sokan tudomást szerezhettek arról, hogy kitört a forradalom, ám a lakosság nagy része megbízható információkhoz napokig nem tudott

\footnotetext{
7 Békés 1973-ban városi rangot kapott.

8 Erdmann, 2006. 15-16. (Érdekes módon erről B. Szabó István személyi dossziéjában semmi sem olvasható.)

9 Bővebben lásd Kávási 1991., Erdmann 1992., Ö. Kovács 2012., Bíró - FÜr 2013.

${ }^{10}$ Lásd Vincze 2013.
} 
hozzá jutni. A többség által hallgatható budapesti rádió pedig az első napokban is „hazudott éjjel, hazudott nappal, hazudott minden hullámhosszon”. Emiatt jó pár napnak el kellett telnie, amíg világossá vált, mi is történt/történik Budapesten.

A tisztánlátást az MDP Békés megyei bizottságának lapja, a Viharsarok Népe sem segítette elő, ugyanis az első napokban még „ellenforradalmi gonosztevőkről” és „aljas provokátorokról” lehetett olvasni benne. ${ }^{11}$

Békés megyében elsőként Gyula ${ }^{12}$ és Békéscsaba (előbbi város 1950-ig, utóbbi az után volt a megye közigazgatási központja) „forradalmasodott”, annak ellenére, hogy október 26-án természetesen mindkét településen érvényes volt a Minisztertanács elnöke, Nagy Imre neve alatt megjelent, a rendkívüli állapot bevezetését elrendelő intézkedés. Aznap este Gyulán háromnégyszáz, Békéscsabán pedig mintegy nyolcszáz-ezerfös tüntető tömeg gyült össze, majd utóbbi helyen megfogalmazták a tizenhat pontból álló követeléseiket. Ebben egyebek mellett követelték a szovjet csapatok kivonását az ország területéről, a statárium eltörlését, szabad, többpárti választásokat és szabad sajtót, az ÁVH megszüntetését, ${ }^{13}$ a sztrájkjogot és „,az egyéni gazdaságokon alapuló parasztpolitikát". ${ }^{14}$ A kinyomtatott tizenhat pontos kiáltvány eljutott Békésre is. ${ }^{15}$

A megye településeinek nagyobb részén másnap, október 27-én, szombaton győzött a forradalom. ${ }^{16}$ Ennek egyik oka az volt, hogy több helyen ekkorra érkeztek haza azok, akik a fövárosban dolgoztak vagy tanultak, és szemtanúként beszámolhattak az ottani eseményekről. A másik ok az, hogy a megyei pártvezetés ekkorra felismerte: ha már nem tudja megakadályozni a számukra nem kívánatos fejlemények kialakulását, hát megpróbálja az események élére állva elvenni a radikális követelések élét.

Békésen az események kulcsszereplője egy korábbi kisgazdapárti vezető, Szatmári István ${ }^{17}$ volt. Ö éppen nem illett bele abba a képbe, amelyet utólag a kádári hatalom igyekezett sulykolni: az újonnan létrehozott „ellenforradalmi szervezetekben a vezetők, s hangadók mindenütt az osztályidegen kulákok, reakciósok, a volt csendőrök, valamint horthysta tisztek voltak." 18 Szatmári szegény, kisparaszti családból származott, csak nyolc holdon gazdálkodott, az állattenyésztés volt a fö megélhetési forrása.

Valószínúleg azután lett a Független Kisgazdapárt (FKGP) helyi szervezetének vezetője, hogy a párt békési alapítója, B. Szabó István 1944. végén az ideiglenes nemzeti kormánynak, majd 1946. elejétől a Nagy Ferenc-kormánynak lett az államtitkára, emiatt időlegesen Budapestre

11 Lásd a Viharsarok Népe 1956. október 24-26-i számait.

12 Bővebben: ERDÉsz 2017.

13 Az 1950-ben önállósított Államvédelmi Hatóságot a Nagy Imre-kormány - a szovjetek utasítására - visszahelyezte a Belügyminisztérium keretébe, tehát 1956-ban már nem létezett önálló ÁVH. Az más kérdés, hogy a hírhedett terrorszervezet a minisztériumon belül továbbra is meg tudta örizni a tényleges önállóságát, mígnem a forradalom első napjaiban gyakorlatilag szétesett.

14 A követeléseket közli Szuromi-Jenei 2004. 25.

15 A már idézett 1957. március 21-i jelentés szerint a „békéscsabai ifúság 12 pontos követelését” az egyik mozdonyvezető hozta magával Békéscsabáról. (Közli VINCZE 2016b. 351.) 1956. október 26-án azonban tizenhat pontos követelést állítottak össze. Utólag az zavarhatta meg a visszaemlékezőket, hogy egy november 19-i, szintén békéscsabai gyülésen tizenkét pontos kiáltvány készült. (Ez utóbbit közli ErdMANN 2006. 213-214.)

16 Hasonló jelenség figyelhető meg a szomszédos megyében, Csongrádban is. Lásd FARKAs, 2006.

17 Szatmári István 1896-ban született, Békésen. Csak egy osztályt végzett, ötven százalékos hadirokkant volt. Apja még uradalmi cseléd volt, ő már hét holdon gazdálkodott.

18 MNL BML Békési Fióklevéltár, a Békés Megyei Tanács VB titkárságának iratai, XIII.6.b. fond, 39. d., 313/1$1957 \mathrm{vb}$. 
költözött. (Az 1956. utáni állambiztonsági iratokban az olvasható, hogy kettejük között rossz volt a viszony - ennek a kérdésnek a vizsgálata azonban messzire vezetne.)

Szatmári István nem volt egy „egyszerü eset” - legalábbis a kommunisták szemszögéböl nézve semmiképpen sem. Az volt ugyanis a szilárd meggyőződése, hogy a sztalinista hatalom jogellenesen vette el tőlük a kisgazda-székházat (melyet egyébként a tagság anyagi áldozatával építettek föl!), és azt mindenáron vissza akarta szerezni. Már 1954-ben azt hangoztatta, hogy „nem bánja, ha a nyaka beleis veszik, de a volt Kisgazda Párt helyiségét visszaveszi” ${ }^{19}$ 1956. október 24-én megjelent a községi tanács végrehajtó bizottságánál (VB), és azt hangoztatta, hogy „Budapesten megkezdődött a forradalom”, és ez „Békés községre is ki fog hatni”. ${ }^{20}$ Ezek után kétszáznegyven kisgazda társa nevében követelte a volt székház visszaadását, mert újjá akarták szervezni a pártot. Követelését természetesen elutasították. Ebbe azonban nem nyugodott bele, és a megyei tanács vezetőségéhez fordult, ám ott sem ért el eredményt.

Október 27-én délelőtt Szatmári egy kisebb csoport élén ismét megjelent a községi tanács épületében, és az FKGP-székház visszaadása mellett már azt is követelte, hogy olvassák be a békéscsabai kiáltványt az ún. „hangos híradóba”. ${ }^{21} \mathrm{Ez}$ megtörtént, de közben egy újabb tömeg a vörös csillag eltávolítását kezdte követelni. (A „csillaghullás” országos jelenség ekkor.) „Leverték a vörös csillagokat a Tanácsházáról, a Nagyházról és a Járásbíróságról. Sok nézője volt a müveletnek..." - emlékezett vissza évtizedekkel később egy szemtanú, Márton László. ${ }^{22}$ Ezt követően egyre többen jelentek meg a tanácsháza előtt, és hangoztatták, hogy a kommunista tanácselnök, Buzás Gábor, és Pető Mátyás községi párttitkár távozzanak a hatalomból. Ekkor azonban még úgy tünt, hogy a régi vezetés kézben tudja tartani az eseményeket. A kommunista tömegszervezet, a Nagy Imre idején létrehozott Hazafias Népfront $(\mathrm{HNF})^{23}$ nevében nagygyülést hívtak össze délutánra a Bérház (a helyi kultúrotthon) egyik kisebb termébe. Ez hangsúlyozottan HNF-kezdeményezés volt, nyilvánvaló taktikai okokból. A szervezők bizonyára arra számítottak, hogy a „hőzöngőket” kizárva az eseményekből, a saját szájuk íze szerint tudják majd alakítani a dolgokat, és ha „forradalmi tanácsot” alakítanak, akkor abba bekerülnek „a végrehajtó bizottság valamennyi tagja és a tanácstagok egy része, különösen a párttagok” ${ }^{24} \mathrm{Ez}$ a trükk azonban nem jött be, mert nem számoltak Szatmári Istvánnal, és a változásokat követelő tömeggel.

A Bérház kistermébe összehívott - kezdetben szűk körű, száz-százhúsz fős - gyülést a HNF helyi titkára, K. L. Szabó Gábor nyitotta meg, majd Buzás Gábor tanácselnök akart szólásra emelkedni, „mivel így gondolták a tömeget nyugalomra bírni.” Csakhogy a tömeg lehurrogta, Szatmári pedig kiragadva kezéből a mikrofont, ${ }^{25}$ „uszító beszédet” mondott. Egyebek mellett kijelentette, hogy „a ti [mármint a kommunista vezetőké - V. G.] időtök lejárt.” Majd a tömeg

19 Lásd Ivacska Pál alhadnagy 1957. február 5-i jelentésében. (Közli: VINCZE 2016b. 35.)

${ }^{20}$ Lásd a Községi Tanács Végrehajtó Bizottságának 1957. március 21-i jelentésében, ahol tévesen október 23-ára tették az eseményt. (Közli VINCZE 2016b 350.) Az FKGP-t egyébként a Rákosi-diktatúra nem tiltotta be, és a pártvezetést sem oszlatta fel, papíron létezett 1956-ban is.

${ }^{21}$ Az ún. hangos híradó még a vezetékes rádiók széleskörü elterjedése előtt arra szolgált, hogy azon a település lakóival közöljék az utcákon elhelyezett hangszórókon keresztül a hivatalos közleményeket.

22 BÉKÉsi MÁRTon 1994a. Márton László 38 évvel később úgy emlékezett, hogy 26 -án volt a „csillagverés”. Ternei László az 1957. április 16-i kihallgatásán szintén ezt a napot említette a gyűlés időpontjának. Rajtuk kívül azonban mindenki 27-ére emlékezett.

23 A HNF-et Nagy Imre kezdeményezésére 1954 októberében hozták létre. Egyéni tagság nélküli, a „párton kívüli dolgozókat” tömörítő kommunista „tömegszervezet” volt, 1989-ben szünt meg.

${ }^{24}$ A Községi Tanács Végrehajtó Bizottságának 1957. március 21-i jelentése. Közli Vincze 2016b. 352.

${ }^{25}$ Nagy Gábor VB-titkár úgy emlékezett, hogy Kremzer Jenő és Gruity György ragadták ki Buzás kezéből a mikrofont. Lásd az 1957. július 25-i tanúvallomásában. MNL BML, Békés Megyei Bíróság, büntetőügyek, Z. Bereczki Sándor, XXV.10.c fond, B.361/1957. 33. 
felé az alábbi kijelentést tette: „hallották kedves magyar testvéreim, hogy forradalmi tanácsot választunk, de ezt kommunisták nélkül válasszuk. Elég volt a kommunista rémuralomból, kommunistákkal le kell számolni. Ki kell őket irtani, mert én, magyar testvéreim az[t] a büdös elvtárs szót nem akarom tovább hallani."26

Az épület előtt ácsorgó több száz fős tömeget felszólította, hogy jöjjenek föl a nagyterembe, ahol majd megválasztják a forradalmi tanács tagjait. A nagyteremben azután többen is felszólaltak. F. Szőke Gábor arról beszélt, hogy ő Budapesten járt, és ott a saját szemével látta, hogy „az ávósok milyen aljas munkát végeztek, hogyan mészárolják az embereket. Az Országház előtt vérfürdőt csináltak." ${ }^{27}$ Meglehetősen parázs hangulat alakult ki. Az egyik visszaemlékező „ellenforradalmár”, Márton László szerint a tömeg követelésére Buzás Gábor tanácselnöknek és Pető Mátyás párttitkárnak ki kellett dobnia az ablakon a teremben lévő Sztálin- és Rákosiszobrokat, sőt, egyesek már azt kezdték kiabálni, hogy dobják a szobrok után a két kommunista vezetőt is. Szerencsére a kialakuló lincshangulatot Szatmárinak sikerült lecsillapítania. ${ }^{28}$ Ennek három év börtön lett a „jutalma”...

Az egyik hangadó egy „kulák”, Z. Bereczki Sándor volt, aki mozgósította - legalábbis az ellene emelt vád szerint - a „kulák barátait”. Ö volt az is, aki Nagy Gábor községi VB-titkárnak nekitámadt, mert őt tartotta felelősnek amiatt, hogy betagosították a földjét. Komoly atrocitás azonban nem történt, legfeljebb némi dulakodás - az már más kérdés, hogy a sértett fél, majd a megtorló hatalom ezt fölnagyította.

Felszólalt egy másik „ellenforradalmár”, a gépállomás akkori igazgatója, Budavári László is. Őt azonban többen megtámadták azzal, hogy ávós tiszt volt, és hogy a Rákosi-rendszer nevezte ki a gépállomás igazgatójának. Egyik sem volt igaz: sohasem volt ávós, „csak” párttag, és nem a Rákosi-érában, hanem a forradalom előtt egy évvel helyezték a békési gépállomásra. (Azért belőle is „ellenforradalmárt” kreáltak 1957-ben...)

A nagygyülés spontán módon megválasztotta a forradalmi tanácsot (melyet a korabeli dokumentumokban legtöbbször forradalmi munkástanácsnak, de olykor nemzeti bizottságnak neveztek). Ennek elnöke Szatmári István lett, helyettese pedig F. Szőke Gábor, a tagok: Domokos Mihály, dr. Durkó Gábor, Elek Gábor, Elek Zoltán, Fehér László, Hőgye Lajos, Kun Endre, Fehér László, Kállai István, Kovács László, Medve János, Soós András, Sitkei Miklós, Szász Gyula, Szűcs Imre, Szűcs Sándor, Ujvári László. ${ }^{29}$

Dr. Durkó Gábor, Szatmári István és a járási rendőr parancsnok, Bartha István főhadnagy javaslatára ekkor szervezték meg a nemzetőrséget. Felszólították a jelenlévő, katonaviselt férfiakat, hogy jelentkezzenek nemzetőrnek, akik majd „, hivatva lesznek arra, hogy a rendet fenntartsák” ${ }^{30}$ Ekkor hozták létre egy „,fegyvert összeszedő bizottságot” is. ${ }^{31}$ Ennek lett a feladata, hogy a párt- és állami funkcionáriusoknál otthon, engedéllyel tartott pisztolyokat és vadászpuskákat begyüjtse.

${ }^{26}$ Lásd Vári András 1957. március 19-i tanúvallomását. (Közli VINCZE, 2016b 37.) Vári nyilvánvalóan hazudott, ugyanis a tanúként kihallgatott jelenlévők közül senki sem hallotta ezt a kifejezést, ennek ellenére bekerült Szatmári ítéletének indokolásába.

${ }^{27}$ Nagy Gábor községi VB titkár 1958. január 30-i feljelentése. Közli VINCZe 2016b. 329-330.

28 BÉKÉsi MÁRTON 1994a.

29 Lásd F. Szőke Gábor operatív dossziéjában a „Forradalmi Munkástanács” másolatban fennmaradt alakuló ülésének jegyzőkönyvét. (ÁBTL, 3.1.5. O-9825, 24.) Egy később készült lista nem egészen egyezik a fentivel, azonban ez a forrás más tekintetben is megbízhatatlan. Lásd a Községi Tanács Végrehajtó Bizottságának 1957. március 21-i jelentésében. (Közli Vincze 2016b. 353-354.)

30 ÁBTL, Keresztes Sándor és társa vizsgálati dossziéja: V-148603., 4.

31 Szatmári István 1957. április 18-i ítélete. Közli Vincze 2016b- 63. (Ehhez hasonló bizottság a megyében összesen tizenöt helyen alakult meg, közöttük Békéscsabán is.) 
A bizottság több csoportra oszlott, és mindenki azokba a kerületekbe ment ki a fegyverek öszszegyüjtésére, amelyekben megfelelő ismeretséggel rendelkezett.

A források ellentmondanak egymásnak abban a kérdésben, hogy az október 27-i gyülésen kit neveztek ki a nemzetőrség parancsnokává: a felvidéki származású Ujvári Lászlót ${ }^{32}$ vagy a volt csendőrt, ${ }^{33}$ Juhász Györgyöt ${ }^{34}$ ? Az tűnik valószínűbbnek, hogy ekkor még mind a nemzetörségnek, mind a fegyver-begyüjtő bizottságnak Ujvári volt a parancsnoka és csak másnap váltotta őt Juhász. (A zavart az okozhatta, hogy a fegyverek összeszedésében ő is részt vett, emiatt utólag többen úgy emlékeztek, hogy az akciót a nemzetőrség parancsnokaként vezette. ${ }^{35}$ ) Ujvári emlékezete szerint mintegy huszonöt-harminc fös volt az általa szervezett nemzetőrség, Juhász György azt vallotta később, hogy azalatt a pár nap alatt, míg ő volt a parancsnok, ötvenhat ember szolgált a keze alatt.

A nemzetőrök onnan szereztek fegyvert, ahonnan lehetett: a helybeli pénzügyőrségtől, a hadkiegészítéstől és a járási rendőrkapitányságról. ${ }^{36}$ Így juthattak néhány pisztolyhoz, pár FÉGpuskához ${ }^{37}$ valamint egy géppisztolyhoz. Szatmári utasítására este négy-öt csoport végig járta a nagyközség belterületét és a tanyavilágot és igyekezett összegyűjteni a fegyvereket. Az eddig megismert források szerint az alábbi személyek vettek részt a fegyverek összeszedésében: Baji Miklós, Bondár János, Fekécs Sándor, Futaki Gábor, G. Varga Gábor, Gruity György, Keresztes Sándor, Kremzer Jenő, Lukács Ferenc, Nyíri Ernő, Pocsai László, Szalkai Imre, Sz. Nagy Gábor, T. Nagy Gábor, Tóth Mihály és Z. Bereczki Sándor. ${ }^{38}$

Az egyik csoportot Juhász György vezette. Fölkeresték Virágos Mihályt, a járási pártbizottság elsőtitkárát (onnan egy vadászpuskát hoztak el a hozzávaló lőszerrel, és egy pisztolyt), majd Csatári Bélát, a járási másodtitkárt, akinél ott találták a járási hadkiegészítő parancsnokság vezetőjét, Bartolák András századost és Nagy Lajos pártfunkcionáriust. Mindhármukat bekísérték

${ }^{32}$ Ujvári László a Pozsony vármegyében fekvő Szencen született, 1913-ban. Apja postatisztviselő volt. Ő tanítóképzőt végzett, de anyagi okok miatt nem dolgozott pedagógusként, hanem pénzügyőrként, majd magántisztviselő lett. Részt vett a második világháborúban. 1943-ban házasodott meg, 1945-ben a felesége miatt Békésen telepedett le és attól kezdve alkalmi munkákból próbálta eltartani a családját. 1955-ben a gyulai megyei bíróság fél év börtönnel sújtotta „izgatás” miatt.

${ }^{33}$ A nemzetőrségek szervezését általában fegyverhez értő emberekre bízták, ezért fordulhatott elő, hogy más településeken is volt csendörök, vagy „horthysta” katonatisztek lettek a szervezők. A megye hatvanhat települése közül kilenc olyan ismert, ahol szintén egy volt csendőrt bíztak meg a nemzetörség vezetésével.

34 Juhász György 1902-ben született Újkígyóson, földműves családban. Eredeti szakmája kovács segéd volt. Csak 1923 és 1925 között szolgált csendőrként, utána gabona- és füszerkereskedő volt. 1940 és 1946 között ötvennyolc hold földet bérelt. 1948-ban két hónapra itélték „vagyonrongálásért”. 1956 előtt kishaszonbérlet formájában nyolc holdon gazdálkodott.

35 „Az ellenforradalmi tanács kinevezte Békés község nemzetörség parancsnokának” - jelentette a megyei rendőrkapitány 1957. február 26 -án Ujváriról. (ÁBTL, 3.1.9. V-143061, 8.) A szemtanú Vári András ugyancsak azt állította, hogy a gyủlésen Ujvárit nevezték ki. Ezzel ellentétben Ivacska Pál alhadnagy 1957. március 30-i jelentése szerint Juhász „alakította meg a fegyveres nemzetőrséget, és az ő parancsnoksága alatt tevékenykedtek beosztottjai.” (Közli VINCZE2016b. 162.) Ő maga azonban úgy vallott, hogy csak október 28-án lett nemzetörparancsnok.

${ }^{36}$ Még október 27-én napközben a Békéscsabai Forradalmi Tanács tagjai végig járták a járási székhelyeket, és mindenhol tárgyaltak egyebek mellett a helyi fegyveres erők parancsnokaival is. Emiatt Békésen sem alakult ki konfliktus a forradalmi vezetés és a rendörség között.

37 A Fegyver- és Gázkészülékgyár (FÉG) 44M típusú karabélya.

38 Egy 1957. március 21-i, a községi tanács VB által készített jelentés tartalmaz egy húsz fös listát. Ez nem egészen egyezik azokkal a személyekkel, akiket a bírósági aktákból sikerült beazonosítani, az eltérés oka nem világos. (Közli Vincze 2016b. 352-353.) 
a békési rendőrségre. Végül kimentek a muronyi és a mezőmegyeri tanácshoz, és az ott talált fegyvereket is összeszedték. Egy másik csoport vezetője G. Varga Gábor volt. Ök fölkeresték Vári Andrást, a békési földmüves szövetkezet ügyvezető elnökét, Nagy Ferencet, Pusztai Jánost, Nyíri Sándort és több vadászfegyvert, pisztolyt és kispuskát vittek be Békésre. Egy harmadik csapatot Lukács Ferenc vezetett, ők Békés-Rosszerdőn gyüjtötték be a fegyvereket. Egy negyedik csoport Szalkai Imre vezetésével a városban keresett föl prominens személyeket, például „az ellenforradalmárok által időközben eltávolított” Toldi Sándor rendőr őrnagyot. ${ }^{39}$

Azalatt, míg a „brigádok” az október 27-ről 28-ra virradó éjszaka a kommunistákat „zaklatták”, Ujvári és Szatmári a különböző ellenőrző posztokra vezényelt nemzetőröket járták végig. Körútjukról visszatérve nagy meglepetés érte őket: a Békéscsabáról kiérkezett katonaság időközben lefegyverzett mindenkit. Ennek az volt az elözménye, hogy Bartolák százados és a békési funkcionáriusok letartóztatásának hírére a Rákosi-rezsimhez hủ békéscsabai katonatisztek akcióba léptek. Egyfelől az egyik békési származású tiszt, Pankotai István százados, mikor hírül vette, mi történik Békésen, és megtudta azt, hogy még a saját apját is letartóztatták, harminc sorkatonával rögtön átment a szomszéd településre, és lefegyverezte a nemzetöröket, az elvtársait pedig kiszabadította a járási rendőrkapitányság épületéből, melyet előzőleg „egy általános rohammal elfoglaltak”. ${ }^{40}$ Másfelől Békéscsabán október 28 -án reggel katonai puccsot kíséreltek meg végrehajtani - ami azonban a forradalomhoz hủ lakosság kiállása miatt megbukott. ${ }^{41}$

A lefegyverzést követő napon, október 28-án a nemzetőrséget újjászervezték - de annak a parancsnoka akkor már Juhász György lett, igaz, csak két napig. (Ujvári szerint a forradalmi tanács az eröszakos magatartása miatt váltotta le.) A forrásokból nem derül ki, hogy ekkor rendelkeztek-e fegyverrel.

\section{A szabadság utolsó napjai}

Az október végi, november eleji napok eseményeiről igen szűkszavúan számolnak be az eddig megismert források. Annyi bizonyos, hogy október végén a két, legtöbb embert foglalkoztató munkahelyen, a gépállomáson és a kosárfonóban sor került a munkástanácsok megalakítására.

Október 28-án elkezdődött az 1948 után ellehetetlenített FKGP újjászervezése is. Ebben dr. Mikó János ügyvéd, aki november 4. után nyugatra szökött, Szatmári István és Z. Bereczki Sándor voltak a legaktívabbak. Egy 1957-es jelentés a párt újjászervezésében B. Szabó István befolyását látta, ez azonban nevetséges, ugyanis ő a forradalom napjaiban mindvégig Budapesten tartózkodott, nem volt ideje a békési dolgokkal foglalkozni.

Békésen is általános sztrájk volt, akárcsak az ország egész területén, és a tanítás is szünetelt. Itt jegyezzük meg, hogy a csekély megbízható forrás hiányában egyelőre nem igazán lehet tudni, hogy a békési általános iskolák, és a gimnázium tanárai, valamint diákjai miként, és milyen formában kapcsolódtak be a forradalom eseményeibe. Nehezen képzelhető el, hogy az október 27-i gyülésen többen ne lettek volna jelen. Sós Sándor járási VB-elnök egy 1957. március 25-i jelentésében mindenesetre az olvasható, hogy „a békési hangulatra egészen december elejéig

\footnotetext{
39 MNL BML, Békés Megyei Bíróság, büntetőügyek, Szalkai Imre és társai, XXV.10.c fond, B.684/1957. 12.

40 Lásd a megyei kiegészítő parancsnokság 1957. január 3-i jelentését. Közli Erdmann 2006. 560.

41 Lásd Lőcsei 1999.; Somlai 2003. 92.; ERdmann 2006. 24-26.
} 
nagyon rányomta bélyegét az a tény, hogy a békési gimnázium tanulói igen aktívan támogatták, vezették az ellenforradalom akcióit - majd később a sztrájkokat, - még az iskolák felé is." ${ }^{2}$

A békési gazdák életében a legnagyobb változást az jelentette, hogy a forradalom napjaiban megkezdődött az erőszakkal létrehozott termelőszövetkezetek felbomlása. Ez a folyamat nem ért véget november 4-ével, hanem még hetekig tartott. Erről egy 1957 tavaszán összeállított - roppant elfogult, olykor egyenesen gyülölködő, hazugságokat tartalmazó - jelentés ${ }^{43}$ szerint Z. Bereczki Sándor ${ }^{44}$ és Csonka Imre ${ }^{45}$ „vezetésével indítottak hajszát a [tan]gazdaság felbomlasztására és az ősi föld visszaszerzésére. Ez a csoport odáig vitte, hogy a gazdaság vezetőinek a megfenyegetésén túl a minisztériumban küldöttségileg jártak el.” Mindehhez hozzátették: „a község egyéb termelőszövetkezeteinek szétbomlasztására is alakultak rombolócsoportok. [...] Ezeknek a bomlasztó csoportok munkájának az lett a következménye, hogy a községünk 8 termelőszövetkezetéből 6 termelöszövetkezetet teljesen szétrobbantottak, a közös vagyont széthordták, elherdálták, amelyeknek helyén hosszú hetek és hónapok fáradságos munkája szükséges, hogy a szövetkezetekhez hű, de megfélemlített agrárproletárok és kisparasztok újjáalakítsák termelöszövetkezeteiket. Ezek a kampányok a karhatalom erősödésével állandóan gyengültek...”.

A forradalmi tanács tevékenységéről - források hiányában - szinte semmit sem lehet tudni. A vizsgálati anyagok között másolatban fennmaradt néhány jegyzőkönyv és utasítás azt mutatja, hogy a testület igyekezett a tanácsi apparátus megbízhatónak tartott dolgozóival a mindennapi adminisztratív ügyeket tovább vinni.

Az Ujvári által újjászervezett nemzetőrséget október végétől már támogatta az elvetélt békéscsabai katonai puccskísérlet után a forradalom oldalára állt hadosztály parancsnoksága. Ennek köszönhetően október legvégén Biczó Gyula alezredes, hadműveleti osztályvezető üzent Békésre, hogy végre tőlük is menjenek át a megyeszékhelyre fegyvert igényelni a járásban működő nemzetőrségek számára. (A többi járás az előző napokban ezt már megtette.) Ujvári - vallomása szerint - ekkor kapott Békéscsabán ötvennégy darab PPS típusú, úgynevezett dobtáras géppisztolyt és hatvanöt szovjet gyártmányú karabélyt, a hozzájuk való nagy mennyiségű lőszerrel, valamint vételeztek százötven nyeles kézigránátot is.

Közben Békéscsabáról a megyei hadkiegészítő parancsnokság föosztályáról Pankotai százados két alkalommal is kivonult Békésre. Első alkalommal, 30-án azért, hogy fölvegyék a kapcsolatot a község és környéke pártfunkcionáriusaival, és „megindítsák a párttagok működését”. (Ennek nem tudni mi értelme volt, hiszen a békéscsabai és a megyei pártbizottság „teljes illegalitásba vonult”.) November 1-én pedig azért vonultak ki, mert úgy hallották, hogy Békésen „igen erős kommunista- és pártellenes, ellenforradalmi beállítottságú tanács működik, amely újabb letartóztatásokra készül”. ${ }^{46}$ Az információk megbízhatóak voltak, de letartóztatásra ekkor még nem került sor. November 3-án, szombaton azonban „bizalmas értesítés érkezett” Békésről

${ }^{42}$ Lásd a Községi Tanács Végrehajtó Bizottságának 1957. március 25-i jelentésében. MNL BML, Békési Fióklevéltár, a Békési Járási Tanács VB Titkárságának szigorúan titkos iratai, 1957, XXIII.217/a fond, 1.

43 Békés község tanácsának VB-a 1957. március 21-i jelentése. Közli VINCZE 2016b. 351-360.

${ }^{44}$ Z. Bereczki Sándor nagybátyja az a B. Szabó István volt, akit a politikai rendőrség már 1945-től „jobboldali kisgazdaként" tartott számon, emiatt az ötvenes évek közepéig figyeltették. Ráadásul 1957-ben - mivel egy napig tagja volt a forradalmi Nagy Imre-kormánynak - három évre ítéltek. Bővebben lásd Mucsi-VINCZE 2013.

45 Ungváry Krisztián szerint 1956 után ő jelentett „Virágos János” fedőnéven. (UnGVÁrY 2013. 115.) E tanulmány szerzőjével évekkel ezelött egy idős békési ember bizalmasan közölte, egy alkalommal Csonka ittasan bevallotta neki, hogy 1956 után évekig jelentgetett...

${ }^{46}$ Lásd a megyei kiegészítő parancsnokság 1957. január 3-i jelentését. Közli Erdmann 2006. 563. 
hogy mégis csak sor fog kerülni erre, és a nagyközségben állomásozó katonai egység vezetőjével „meg is állapodtak a kivégzések végrehajtásáról” ${ }^{47} \mathrm{Ez}$ a hamis hír ${ }^{48}$ minden bizonnyal valamelyik helyi pártfunkcionáriustól származott. Sem a rendőrségi vizsgálatok, sem pedig a bírósági tárgyalások során nem merült fel komolyan ilyen vád. Az értesülés azonban annyiban mégis csak igaznak bizonyult, hogy szombaton újabb akció történt a helyi kommunisták letartóztatására. Az este folyamán Ujvári László nemzetőr-parancsnok kapott egy tizenöt-húsz nevet tartalmazó listát. ${ }^{49}$ Azt megnyugtatóan nem sikerült tisztázni az 1957-es megtorlás idején, hogy ezt a névsort ki állította össze, és ki írta alá. Bár Szatmári István igyekezett kimagyaráznia magát (nem volt nála a szemüvege és nem látta, hogy mit írt alá - vallotta több alkalommal is), mégis csak az a valószínű, hogy ő volt az akció kezdeményezője.

Ujvári néhány nemzetőrrel és kiskatonával kiment a VII. kerületbe, majd letartóztattak négy párttagot. Őket, valamint a kísérőiket egy volt csendőr, Herpai László ${ }^{\boxplus}$ segítségével szállították be Békésre. Ott a többi, mások által begyűjtött párttagokkal és funkcionáriusokkal együtt Herpai teherautóján átvitték őket a békéscsabai laktanyába.

Természetesen a békési kommunisták nem sokáig maradtak Békéscsabán, hiszen 3-án hajnalban már bent voltak a szovjet megszállók a városban. A laktanyából egyszerűen visszaküldték őket Békésre, majd az ottani rendőrségről 4-én estefelé egyenként haza engedték őket.

\section{A forradalom utóvédharca}

Számunkra nehezen érthető, Szatmári István miért éppen november 3-án határozta el, hogy begyüjtet néhány békési pártfunkcionáriust vagy egyszerű párttagot azzal a céllal, hogy a békéscsabai laktanyába szállíttassa, hiszen arról már tudnia kellett, megindult az újabb szovjet invázió. A Békés Megyei Forradalmi Tanács napilapja már a november 3-i számában azt írta, hogy két nappal (!) korábbi hírek szerint „Debrecenből Békéscsaba irányába kb. 360 harckocsi, gépkocsi, löveg és páncélozott gépkocsi indult el. [...] Az előrenyomuló oszlop Békést 5.30 órakor érte el és folytatta az útját Békéscsaba irányába." ${ }^{50}$ Juhász György 1957. április 8-i kihallgatása alkalmával felmerült az, hogy egy csoport állítólag meg akarta támadni a szovjeteket ${ }^{51}$ - ez azonban nem „életszerü” történet. Valószínüleg ugyanolyan koholmány, mint az, hogy az összeszedett párttagokat és funkcionáriusokat november 4-én ki akarták végeztetni...

A szovjet katonai oszlop tehát november 3-án még csupán keresztül vonult Békésen, nem állt meg. Nyilvánvalóan azért, mert a legfőb feladat a megyeszékhely „pacifikálása” és a katonai ob-

47 Uo. 564.

48 A „magára találó” megyei pártlap, a Békés megyei Népújság egy november 12-i felhívásában azt hazudta, hogy „Véres terrorcselekményekre készültek, mint például Békésen...”

49 A letartóztatottak között volt Buzás Gábor tanácselnök, a helyettese, Tarr Lajos, Pető Mátyás VB-tag, Virágos Mihály, az MDP járási elsőtitkára, Csatári Béla másodtitkár, Nagy Lajos harmadtitkár, ifj. Gólya János tsz.elnök, Vári András, a földműves szövetkezet ügyvezetője, id. Pankotai István tsz-tag, Nagy Jenő és Pusztai János párttagok.

50 Kossuth Népe 1956. november 3. („Szovjet csapatmozdulatok Békés megyében”) Filep Tibor debreceni kutató szerint Debrecent november 3-án zárták körül a szovjet katonai egységek, tehát aznap indulhatott el egy oszlop Békéscsaba irányába. (Filep 1991. 139.)

51 Lásd Juhász György 1957. április 8-i kihallgatását (Juhász György és társai vizsgálati dossziéja, 3.1.9. V-144931, 21-24.). 
jektumok megszállása volt. Békésre november 5-én vagy 6-án ${ }^{52}$ este vonult be egy szovjet alakulat, három páncélossal. Körbefogták a rendőrséget, a nemzetőröket hazaküldték, a parancsnokot, Ujvárit magukkal hurcolták, Juhász Györgyöt pedig a hó végéig házi őrizetben tartották, majd a rendőrség őrizetbe vette. ${ }^{53} \mathrm{~A}$ békéscsabai kihallgatása után azonban 7-én visszavitték Békésre. Ott Pankotai István százados „azt mondta a VB-tagoknak, hogy ne tartsunk haragot, dolgozzunk együtt. A forradalmi tanács ezen a napon megszünt." - vallotta utóbb. ${ }^{54}$ Ö azonban rosszul emlékezett, ugyanis a forradalmi tanács ekkor még nem szünt meg.

A forrásaink ellentmondásosak ugyan, de annyi bizonyos, hogy november 5-én a nemzeti bizottság (most ilyen néven!) Szatmári István vezetésével még ülést tartott és különböző intézkedéseket hozott. ${ }^{55}$ Aznap azonban - legalábbis a községi tanács VB már idézett, kétes értékü, pontatlan, 1957. március 21 -i jelentése ${ }^{56}$ szerint - a tanács/bizottság tagjait letartóztatták, majd a tanácsházán felhívták a figyelmüket arra, hogy „a törvényesen elismert tanácsvezetők továbbra is a régiek” a forradalmi tanács pedig „javaslattevő, véleményező" szervként csak abban az esetben működhet tovább, ha „elismerik az ideiglenes Forradalmi Munkás-paraszt Kormányt és felelős vezetőknek a helyi vezetőket.”

Ettől kezdve egy sajátos kettős hatalom alakult ki Békésen. (Ez az egész megyében így volt november végéig. Országos szinten a kádári hatalommal szembeni ellenpólust a munkástanácsok képezték, azok erőszakos felszámolásáig.) A még 1954-ben „megválasztott” községi tanács végrehajtó bizottsága újjáalakult ugyan, de annak munkájába bevonták a forradalmi tanács két vezetőjét, Szatmári Istvánt és Szivák Zsigmondot is azzal, hogy ők képviselik az utóbbi testületet. A Végrehajtó Bizottságon belül - a tömegek nyomására - kezdettől fogva fölmerült az, hogy egyes kompromittált tagokat (Buzás Gábort és Pető Mátyást) távolítsák el a pozíciójukból. Ez meg is történt, mindketten lemondtak. Vita folyt arról is, hogy a teljes VB-nak le kellene-e mondania. Szivák azzal érvelt, hogy „a forradalmi tanácsot a nép választotta...”, míg Szatmári nem kertelt, és kijelentette: „soha sem fér két dudás egy csárdában. A községre is rossz hatással van, mert nem tudják, hogy ki a község feje." ${ }^{57}$ Végül a kérdést megszavaztatták, minek eredményeképpen a régi rendszert képviselő, jelképező végrehajtó bizottság tagjait fölmentette a községi tanács. A tényleges vezetés hetekig egy tizenegy tagú végrehajtó bizottság kezében volt.

Ez a kettős hatalom a közigazgatás területén nem tartott sokáig. November 24-én a Békés Megyei Tanács Végrehajtó Bizottsága utasította a járási és városi VB-elnököket, hogy akiket az „utóbbi időben” (értsd: október 23. után) „jogtalanul” elbocsátották, vissza kell venni, és akiket helyükben (a forradalom napjaiban) „jogosulatlanul alkalmaztak”, azokat pedig ki kell rúgni. ${ }^{58}$ A hatalom akkori gyengeségét azonban mégis csak jelezte az, hogy megfontolandónak tartották

52 A legtöbb irat november 6-át említi a szovjet bevonulás napjaként, ám Juhász György szerint egy nappal korábban történt az esemény. Lásd az 1957. április 8-i kihallgatását és az augusztus 29-i ítéletet. (MNL BML, Békés Megyei Bíróság, büntetőügyek, XXV. 10. c fond, B.458/1957. 32.)

53 Egy disszertációban az olvasható, hogy a megyében legtovább, 17-ig Békésen „állt fenn az eredeti nemzetőrség”. Az nem derül ki, hogy ezt milyen forrás alapján állítja a szerző. Lásd BoKoDI-OLÁH, 2014. 73.

54 Lásd Ujvári László bűnügyének 1957. december 4-i tárgyalásáról fölvett jegyzőkönyvet (MNL BML Békés Megyei Bíróság, büntetőügyek, XXV. 10. c. fond, B. 786/1957. 85-99.).

55 Lásd azF. Szőke Gábor operatív dossziéjában található, hitelesített jegyzőkönyv-másolatot. ÁBTL, 3.1.5. O-9825, 27-28.

56 Közli Vincze 2016b. 350-360.

57 Lásd a Községi Tanács Végrehajtó Bizottságának 1956. november 20-i jelentését. (MNL BML Békési Fióklevéltára, XXIII. 6/b. fond, 39. doboz, a megyei tanács VB titkárságának iratai, 29-30.)

58 Békés megyei Népújság 1957. november 27. („A Megyei Tanács Végrehajtó Bizottság utasítása”) 
- legalábbis a november 27-i megyei pártlap szerint - azt az egy hónappal korábbi követelést, miszerint a városi és járási pártbizottság épületét adják át lakások céljára...

Ezalatt a „rendpárti erők” sem tétlenkedtek: az a Pankotai István százados, aki a forradalom napjaiban több alkalommal kivonult Békésre, hogy megmentse az ottani kommunistákat, november közepén „megindította a járási székhelyeken a polgári népőrségek karhatalmi szervezését”, és ez „sikerrel járt” a békési járásban is. ${ }^{59}$ Pankotai, november 20 . körül lett a megyei karhatalmi alakulat ${ }^{60}$ parancsnoka, és mindent megtett annak érdekében, hogy a „munkás-paraszt hatalom megszilárduljon”. Így például ismét kivonult Békésre, és „végigjárta az üzemeket, melynek eredményeképpen az üzemi munkástanácsok küldötteivel egy nap alatt leváltatta a volt fasiszta beállítottságú forradalmi tagokat.”'11 Közben a járásban elkezdődött az MDP utódpártja, a Magyar Szocialista Munkáspárt helyi alapszervezeteinek a szervezése, ezáltal is erősítve a Moszkvából az országra kényszerített Kádár-féle bábkormány helyi hatalmát.

Bár a karhatalmisták (közkeletű nevükön a „pufajkások”) igyekeztek megfélemlíteni az „ellenforradalmárokat”, ez az első hetekben még sem sikerült. Az ellenállást nem lehetett olyan könnyen letörni a Viharsarokban sem. „Az 1956. november 4-e utáni időket figyelembevéve Békés megye olyan sajátos helyzetben volt, hogy amíg az ország különböző részein november-decemberben a rend viszonylag helyreállt, addig ebben a megyében novemberben és még december első felében is komoly, és nyílt ellenforradalmi tüntetések, megmozdulások voltak" - olvasható a megyei rendőr-fökapitányság egyik 1960-as jelentésében. ${ }^{62}$ Ebben egyebek mellett arra utaltak, hogy a megyében Gyulától Szarvasig, és Battonyától Füzesgyarmatig szinte minden településen 1956. december 6. és 10. között tömegtüntetéseket tartottak, helyenként atrocitásokra is sor került. ${ }^{63}$

Békésen a forradalom híveinek utolsó tömeges megmozdulására is ezekben a napokban került sor, méghozzá két alkalommal is.

Az első demonstráció célja két letartóztatott személy: Juhász György és Domokos Mihály egyetemista kiszabadítása volt. Az akció főszervezője, Márton László erről úgy emlékezett vissza évtizedekkel később, hogy december 4-én este eljutott hozzájuk az a hír, miszerint a Budapesten tanuló orvostanhallgatót elhurcolták a szülei házából, mert a házkutatás során megtalálták azokat a fényképeket, melyeket a Széna téri harcok idején készített. Rögtön elhatározták, hogy szimpátiatüntetés szerveznek az ő, és Ujvári László kiszabadítása érdekében. Úgy tűnik azonban, Márton Lászlót ismét megcsalta az emlékezete, ugyanis az összes nyomozati és bírósági iratban az olvasható, hogy az egyetemistán kívül Juhász György kiszabadítása volt a cél. Az ő elsőfokú ítéletében is az olvasható, hogy december 6-án azért helyezték szabadlábra, „mivel Békésen

59 Lásd a megyei kiegészítő parancsnokság 1957. január 3-i jelentését. Közli ErdmanN 2006. 567.

60 A karhatalmi ezredek felállítását a Kádár-kormány még a november 7-i ülésén határozta el. Lásd ZINNER 2001. 72 .

61 ERdmann 2006. 568. A fenti idézethez csupán két megjegyzést füzünk. Egyrészt azt, hogy éppen ki a „fasiszta beállítottságú”, 1945-től évtizedeken át mindig a kommunisták döntötték el. Másrészt, ismerve az 1956. november 4. utáni megtorlás országos eseményeit, el tudjuk képzelni azt, hogy Pankotai elvtárs Békésen az állig felfegyverzett, és bosszúszomjas karhatalmistáival - akiknek nagy része pár héttel korábban még ávós volt! - milyen módszerekkel tudott „rendet teremteni” az üzemi munkástanácsoknál.

62 A BM Békésmegyei Rendőrfőkapitányság 203-647/1960. sz. „Szigorúan titkos!” jelzésű jelentése a „belsőreakció elleni harc értékeléséről”. MNL BML, Békési Fióklevéltár, MSZMP-archívum, 1. fond, 14. fondcsoport, 9. örzési egység, 40.

63 Például Battonyán leszerelték a rendőrséget és a határőrséget, Mezőkovácsházán ugyancsak „semlegesítették” a rendőrséget, Gyulaváriban pedig feldúlták a pártházat. Békés megyei Népújság, 1956. december 11. („Forradalom vagy nemzeti forradalom?") 


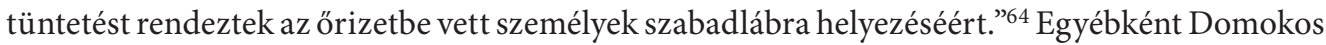
Mihály kiszabadítása azért nem sikerült, mert őt már korábban átszállították Békéscsabára. Későbbi sorsáról semmiféle forrás sem áll a rendelkezésünkre.

Ami a másik demonstrációt illeti, arra - Juhász György 1957. április 8-i vallomása szerint - az „ellenforradalmi tanácstagok” kezdeményezésére került sor. Ekkor egy koszorúzással egybekötött néma tüntetést tartottak, tiltakozásul a forradalom vérbefojtása miatt. A december 5-én meghozott határozatról Juhász értesítette volt nemzetőrtársait azzal, hogy lehetőleg mindenki legyen jelen a másnapi demonstráción. (A jegyzőkönyv szerint állítólag azt is bevallotta, utasította a társait, hogy a némán tüntető tömeget két oldalról biztosítsák, nehogy „a kommunisták”, vagyis a kivezényelt karhatalmisták meg tudják zavarni a demonstrációt. Ugyancsak ekkor vallotta azt is, hogy „ha a tömeg kezdeményez valamit, akkor akcióba kell lépni, a rendőrkapitányságot kell lefegyverezni”. ${ }^{65}$ Bár erről mások is beszéltek a kihallgatásukon, nem zárható ki, hogy ennek semmiféle valóságalapja sincs és csupán a kihallgatást vezető rendőrök erőltették ezt. Árulkodó ugyanis, hogy az elsőfokú ítélet szövegében erről már semmi sem olvasható...) Míg Juhász György a volt nemzetőröket mozgósította, addig Szivák Zsigmond a pedagógus kollégáit. Utóbbinak köszönhetően a tüntetőkhöz csatlakozott a gimnázium teljes tanári kara, beleértve az igazgatót, Polgár Lajost is, ${ }^{66}$ valamint a diákok jó része. Erről a néma tüntetésről egyébként röviden beszámolt a megyei pártlap: „délelőtt fél 11 órakor a Békési Gimnázium tanulói, üzemek dolgozói, zászlókkal és koszorúkkal vonultak a község főterére, hogy a hősök emlékmüvénél leróják kegyeletüket. A felvonuló 1500 főnyi tömeg semmilyen jelszavakat nem hangoztatott." 67 Az egyik szemtanú, Márton László ${ }^{68}$ úgy emlékezett, hogy a demonstráció még sem volt egészen néma, ugyanis Demeter Sándor evangélikus lelkész elszavalta Reményik Sándor erdélyi költő „Ahogy lehet” címü legendás versét, míg ő Petőfi „Nemzeti dal”-át.

A két esemény időpontjára utólag sokan rosszul emlékeztek vissza, feltehetően azért, mert ezek összemosódtak az emlékezetükben. Az 1957. április 8-i kihallgatásán Juhász György a december 6-i dátumot ${ }^{69}$ említett a néma tüntetéssel kapcsolatban, ám később már ő és társai is 10-ére tették ezt az eseményt, emiatt az elsőfokú ítéletben következetesen a december 10-i néma tüntetésre hivatkozik a bíróság. Mindezek ellenére úgy gondoljuk, legnagyobb valószínüséggel az a pontos dátum, amely az esemény után két nappal, december 11-én, kedden megjelent pártlapban olvasható: december 9. vasárnap. A szervezők feltehetően tisztában voltak azzal, hogy az embereket legkönnyebben a vasárnapi istentisztelet, illetve szentmise végeztével lehet demonstrációra hívni. Hónapokkal később, a kihallgatások során már könnyen előfordulhatott, hogy a terheltek nem emlékeztek pontosan arra, hányadikára is esett a tüntetés vasárnapja. Az idősíkok egybecsúszásával magyarázható az is, hogy a rendőrség megtámadásának tervét a néma tüntetéssel kapcsolták többen össze. Ha ez egyáltalán valóban felmerült, szerintünk mindenképpen Juhászék kiszabadításához köthető.

\footnotetext{
64 VINCZE 2006b. 185.

65 VINCZE 2006b. 165. (Erről a tervezett akcióról Berczi Gábor is beszélt a március 26-i kihallgatásán, azt állítva, hogy Juhásztól hallott erről.)

${ }^{66}$ Lásd az 1957. március 20-i jelentést a pedagógusok magatartásáról. MNL BML, Békési Fióklevéltár, a Békési Járási Tanács VB Titkárságának szigorúan titkos iratai (1957), XXIII.217/a fond, 5.

${ }^{67}$ Békés megyei Népújság, 1956. december 11. („Koszorúzási ünnepség Békésen”)

68 Márton László szerint „a szovjet bejövetel második napján”, november 5-én volt a néma tüntetés. Bár az események résztvevője volt, az időpontban biztosan megcsalta az emlékezete. (BÉKÉsı 1994a)

${ }^{69}$ Ezen a napon volt a gyulai demonstráció is. Lásd ERDÉsz 2017.
} 
Az eseményekkel kapcsolatos bizonytalanságot csak fokozza az, hogy a községi tanács VB már idézett 1957. március 21-i jelentésében már egy újabb tüntetést említenek: „december 20-a körül a rendőrség és a karhatalom ellen felvonultatott kosárüzemi munkások, diákok és gépállomási dolgozók tömeges részvétele abból a célból, hogy a rendőrség és a karhatalom által letartóztatott Domokos Imre többszörös gyilkos és Ujvári és Juhász csendőrök, továbbá Budavári László gépállomási ig. kiszabadítását követeljék..."70 Ehhez csupán annyi megjegyzést füzünk, hogy Domokos Imre keresztneve helyesen Mihály, és nem volt „többszörös gyilkos”, Ujvári László pedig sohasem volt csendőr - és őt ugyanúgy nem akarták kiszabadítani, mint Budavárit, mert akkor még le sem voltak tartóztatva...

\section{A megtorlás}

„Az ellenforradalmi akciók felszámolása elég vontatottan indult meg.” - olvasható a Békés megyei Rendőrfőkapitányság már idézett, 1960-as jelentésében. ${ }^{71}$ A békési forradalmárokkal szembeni eljárás 1956 decemberében vette kezdetét. Az alaphangot már egy hónappal korábban megadta a „Munkások, parasztok politikai napilapja”, vagyis a (szerkesztőségi munkatársainak összetétele, és szellemisége szerint régi/új) megyei pártlap. Egyik kirohanásában ugyanis apokaliptikus képet festett az „ellenforradalom” kitörése utáni időszakról. „Lidércként ülik meg még ma is sok becsületes embernek szívét, lelkét az ellenforradalmi elemek tettei, akik a nagy nemzeti mozgalmat ${ }^{72}$ beszennyezték.” - kezdte a névtelen sajtómunkás. „Vegyük csak Juhász Györgyöt - folytatta a lap -, volt horthy-csendőrt, aki Békésen a rendfenntartó közegek parancsnoka lett, a lefogottak ajtajában szétvetett lábbal állt meg egy esetben és ezeket mondta: »Szép kis társaság... Miért nem énekelnek...?« És kik voltak ennek a »szép kis társaságnak» a tagjai? Olyan közbecsülésnek örvendő emberek, mint Tarr Lajos, a békési tanács VB elnökhelyettese, volt 9 holdas paraszt." ${ }^{73}$ A kommunista firkász végül víziójában eljutott az 1919-es ellenforradalmi megtorlásokig, azok szimbolikus településéig, Orgoványig és Siófokig. A cél nyilvánvaló: mindazok, akik részt vettek a kommunista funkcionáriusok lefegyverzésében, a „Horthy-terrorhoz” időszakához szerettek volna visszatérni.

Az 1956-os forradalom leverését követő jogi megtorlások békési ügyeit két nagy csoportba lehet osztani: 1.) egyesekkel szemben alapvetően a forradalom néhány napjai alatt elkövetett „büneik” miatt emeltek vádat; 2.) másokat amiatt vontak felelősségre, mert nem tudtak beletörődni a forradalom leverésébe, és talán a csodában (vagyis abban, hogy a „jenkik” mégis csak megjönnek, és megszabadítják az országot a szovjet uralomtól) bízva november 4. után tovább éltették a forradalom szellemét (falfirkák, röpcédulák terjesztése által) vagy valamilyen szervezkedésbe kezdtek. (Juhász György mindkét kategóriába besorolható.)

Mielött röviden összefoglalnánk a békési forradalmárok ellen lefolytatott eljárások lényegét, mindenképpen föl kell hívnunk néhány lényeges dologra a figyelmet.

\footnotetext{
70 Közli Vincze 2016b. 359.

71 A BM Békésmegyei Rendőrfőkapitányság 203-647/1960. sz. „Szigorúan titkos!” jelzésű jelentése a „belsőreakció elleni harc értékeléséről”. MNL BML, Békési Fióklevéltár, MSZMP-archívum, 1. fond, 14. fondcsoport, 9. örzési egység, 40 .

72 Novemberben még lehetett „nagy nemzeti mozgalomnak” titulálni a forradalmat, decembertől kezdve azonban már nem.

73 Békés megyei Népújság 1956. november 8. („Ma már szabadon ölelik keblükre hitveseiket, gyermekeiket”)
} 
Mivel az események után több, mint fél évszázad telt el, az, hogy a letartóztatott, és bíróság elé állított személyekkel mi történt, kizárólag a kádári megtorló hatalom, tehát a politikai rendőrség, ügyészség, bíróság által „termelt” iratokból rekonstruálható - úgy-ahogy. Ezek az iratok sok mindent „elmondanak” a témát valamelyest ismerő kutatónak, de sokat nem. Így például nem tudhatjuk azt, (ha csak egy-egy érintett személy leszármazottja utólag nem meséli el), hogy 1956 novemberében a karhatalmisták, vagyis a gyülölt „pufajkások” mit müveltek Békésen. Hány embert vertek meg, hányat hurcoltak magukkal mindenféle rendőrségi határozat, bírósági végzés nélkül. Egyelőre arról sem találtunk kimutatást, hogy Békésről összesen hány embert internáltak.

Az is csupán néhány esetben ${ }^{74}$ derült ki, hogy a kihallgatás során, a rendőrségen csak verés hatására írta alá a gyanúsított az önmagára, vagy másokra terhelö vallomást tartalmazó jegyzökönyvet. Arra is érdemes fölfigyelnünk, hogy a vád tanúinak nagy része - bár „érdektelennek” nyilvánította magát - sértett fél volt, és minden áron börtönbe akarta juttatni az „ellenforradalmárt”. Ez elsősorban a nemzetőrök, a fegyver-begyüjtő csoportok tagjai esetében feltünő jelenség. ${ }^{75}$ Olykor a tanúk összebeszélésének gyanúja is felmerül. A vádat minden esetben kizárólag a vizsgálati szakaszban „produkált” gyanúsítotti- és tanú-vallomásokra alapozták. A tárgyalás végén pedig - ha egyáltalán beidézték a védelem összes tanúját - döntően az ügyész tanúinak vallomásaira, illetve a nyomozati szakban produkált jegyzőkönyvi vallomásokra alapozva hozta meg ítéletét a bíróság. ${ }^{76}$

Összefoglalóan azt mondhatjuk, hogy az 1956 utáni, békési vonatkozású pereket nem tekinthetjük olyan „klasszikus” koncepciós pereknek, mint amelyek a Rákosi-korszakból ismertek (amikor az ítéletben megfogalmazott tényállás köszönő viszonyban sem volt a valóban megtörtént eseményekkel), ám ezek is politikai színezetű bírósági eljárások voltak. A vád valamennyire megalapozott volt ugyan, (például a vádlott valóban tagja volt a fegyver-összeszedő bizottságnak, de senkit sem bántalmazott), ám az elkövetett cselekmény súlyánál jóval súlyosabb ítéletet szabtak ki, mert ezt „kellett” tenni egy „ellenforradalmár” bünügyében.

Érdekes módon elsőként nem a békési forradalom vezetőjét, Szatmári Istvánt tartóztatták le, hanem az egyik volt nemzetőrt, G. Varga Gábort. Öreá valószínűleg azért figyeltek fel, mert Fazekas János rendőr hadnagy december 20 -i szóbeli bejelentése szerint valamikor december 7 . és 10. között a gépállomás dolgozóit sztrájkra szólította fel. Még december 20-án ôrizetbe vették. Az ellene megindult nyomozásból „bontakozott ki” egy „ellenforradalmi bünügy”, vagyis az, hogy a két nappal később őrizetbe vett G. Varga tagja volt a fegyver-begyüjtő bizottságnak, és november 3-án ő is részt vett néhány kommunista Békésre történő bekísérésében. Az 1957. március 8-i, elsőfokú ítélete annyiban érdekes, hogy az indoklásban az olvasható, miszerint „közreműködött Ujvári László nemzetőrparancsnok törvényellenes cselekményeiben"77 - akit csak hónapokkal később tartóztattak le. Első fokon a járásbíróság „termelőszövetkezet elleni izgatás és egyéb büntett miatt” ítélte hat évre. A megyei bíróság azonban az ítéletet megsemmisítette, és pótnyomozást rendelt el, mert a járásbíróság (illetve a nyomozó hatóság) „az ügyet kellően nem derítette fel”, vagyis nem emelte ki G. Varga Gábor büncselekményének „ellenfor-

${ }^{74}$ Lásd Márton László, Szatmári Imre és Papp Imre, valamint Szabó Gábor esetét. MNL BML, Békés Megyei Bíróság, büntetőügyek, XXV. 10. c. fond, B. 786/1957. 124. és VINCZE 2016b. 207.

75 Vári András, a földműves szövetkezet ügyvezető elnöke eleve nem lehetett elfogulatlan tanú Szatmári Istvánnal szemben, hiszen utóbbi a szövetkezet kezelésében lévő volt FKGP-székházat akarta - már a forradalom kitörése elött is, majd annak leverése után is - visszaszerezni.

${ }^{76}$ Megjegyezzük, hogy az 1945 és 1950 között mủködő népbíróságok esetében ugyanez volt a gyakorlat!

77 Lásd az 1957. március 8-i ítéletet (MNL BML, Békés Megyei Bíróság, büntetőügyek, XXV. 10. c fond, B.527/1957. 11-13.) 
radalmi" jellegét. Az elrendelt nyomozás-kiegészítés eredményeképpen kiderült, hogy a február óta internálótáborban lévő Ujvári László nemzetőr-parancsnok (másik verzió szerint Szatmári István) utasítására részt vett „komunisták lefegyverezésében, és letartoztatásában, elhurcolásában, mindezt kihangsúlyozta ő maga azért, hogy a komunista rendszert megdöntse" ${ }^{78}$ Ennek eredményeként a megyei bíróság már „a népi demokratikus államrend megdöntésére irányuló mozgalomban való tevékeny részvétel büntettében” látta bűnösnek. A meglepő az, hogy annak ellenére, hogy most „ellenforradalmárként” ítélték el, az elsőfokú ítéletben megfogalmazott büntetés mértékét több, mint a felére csökkentették le, és G. Varga Gábor megúszta két év, négy hónap börtönbüntetéssel.

Budavári Lászlót, ${ }^{79}$ az állami gazdaság igazgatóját - G. Varga Gábor ügyével összefüggésben - ugyancsak 1956. december 20 -án vették őrizetbe. A december 21-i kihallgatása alkalmával azt vallotta, hogy a munkástanácsot a távollétében választották meg, majd amikor behívták a munkahelyére, kinyittatták vele a páncélszekrényt, és az ott lévő iratokat el akarták égetni. Erre ő kérte, hogy legalább a mérlegbeszámolókat hagyják meg. Ez így is történt, csak a pártiratokat tüzelték el az udvaron. Amikor az összegyült dolgozók követelték a párttitkár távozását, ő igyekezett védeni, majd kijelentette: „semmiféle szervezkedésben részt nem vettem és arról sincs tudomásom, hogy ilyen szervezkedésben bárki részt vett volna.” Annyit ismert el csupán, hogy úgy két héttel korábban valaki megjelent a gépállomás területén, és az ott tartózkodó dolgozókat arra biztatta, „hogy vonuljanak fel a rendőrség elétüntetni, mert elhurcoltak egy egyetemistát és a volt nemzetőr parancsnokot. Ezeknek a személyeknek a szabadonbocsátása lett volna a követelés, mely írásban is le volt fektetve. Én, és több idősebb dolgozó közöltük vele, hogy nekünk tudomásunk nincs arról, hogy nevezetteket miért hurcolták el és kik azok, ezért ebben az akcióba nem avatkozunk bele. Ennek ellenére a gépállomás dolgozói közül kerültek fiatalok, akik azt mondották, hogy ők résztvesznek ezen." ${ }^{80}$ Ekkor még Volent főhadnagy csak arra volt kíváncsi, mit tud G. Varga Gábor „ellenforradalmi” tevékenységéről. 1957. február 24-én az előzetes letartóztatásából ugyan kiszabadult, de nyomban „közbiztonsági őrizetbe” helyezték, vagyis leinternálták. Kistarcsáról három hónapon belül kiszabadult, ám ezt követően kétszer is előzetes letartóztatásba helyezték. (Az az iratokból nem derül ki, hogy egy hét után miért engedték szabadon két alkalommal is.) Szeptember 4-én ismét letartóztatták. Az augusztus 26-i vádirat szerint „az ellenforradalom oldalára állt”, mert „élenjárt a sztrájk szervezésében”, ${ }^{81}$ és szerepe volt az eltávolítandó kommunisták listájának összeállításában. 1957. december 5-én hét hónap börtönbüntetésre ítélték, éppen annyi időre, amennyit előzetes letartóztatásban egyébként is eltöltött. ${ }^{82}$

A következő „ellenforradalmár”, aki a politikai rendőrség célkeresztjébe került, a nemzetőrség első, és utolsó parancsnoka, Ujvári László volt. „Szociális származása”" ${ }^{3}$, előélete alapján

78 Lásd Szekeres Sándor alhadnagy 1957.június 18-i jelentését (MNL BML, Békés Megyei Bíróság, büntetőügyek, XXV. 10.c fond, B.527/1957. 54-56.)

79 Budavári László 1925-ben született Abonyban. Az apja mozdonyvezető volt, ő 1947-ben kereskedelmi érettségit szerzett. Csepelen előbb marósként dolgozott, majd főművezető lett, és esti tanfolyamon elvégezte a Műszaki Főiskolát. 1955 novemberében, mint „kiemelt káder” került a békési állami gazdaság élére. Még 1947-ben lépett be az MKP-ba, később három hónapos pártiskolát végzett.

80 ÁBTL, Budavári László operatív dossziéja, 3.1.5. O-14943/106, 4.

81 MNL BML, Békés Megyei Bíróság, büntetöügyek, XXV. 10.c fond, B.766/1957. Az 1957. augusztus 26-i 1957. Tük.Bül.010. sz. vádirat, 2 .

82 A Juhász László és társai per mindegyik tagja egy év alatti börtönbüntetést kapott.

831945 után a bírósági gyakorlat az volt, hogy az adott bűncselekmény megítélésekor minden esetben figyelembe vették a vádlott „szociális származását”, múltját. Ha például ő maga, vagy a család bármelyik tagja 
nem tünt „született ellenforradalmárnak”. 1957 februárjában közbiztonsági orrizetbe helyezték, vagyis a kistarcsai országos internálótábor foglya lett. A fél éves internálást követően, 1957. július 20 -án azonnal előzetes letartóztatásba került. Ügyében elég későn került sor a vádemelésre, ami talán azzal magyarázható, hogy a megye összes ügyésze ekkor igen leterhelt volt. Öt végül több tárgyalási forduló után a megyei bíróság 1958. február 8-án három és fél év börtönbüntetésre ítélte. Március 10-én a Legfelsőbb Bíróság büntetését két évre mérsékelte. ${ }^{84}$

Szatmári István, a forradalmi tanács/bizottság elnöke ellen is elindult a nyomozás, még 1956 decemberében, ám „csupán” 1957. március 12-én tartóztatták le. Ő még szerencsésnek mondhatta magát. Először ugyanis „személyes szabadság megsértésének”, „társadalmi tulajdon hanyag kezelésének”, valamint „termelöszövetkezet elleni izgatás” bűntettének elkövetése miatt ítélték három év és két hónap letöltendő börtönbüntetésre ${ }^{85}$ Azt követően, hogy a bíróság az ügyét átminősítette, „a demokratikus államrend megdöntésére irányuló mozgalomban való tevékeny részvétel bűntette miatt”, a megyei bíróság csak két hónappal súlyosabb büntetést szabott ki.

Az a fennmaradt iratokból nem derül ki, hogy Márton László ${ }^{\bigotimes}$ hogyan került a politikai rendőrség célkeresztjébe. Annyi bizonyos, hogy még 1957 márciusában tartóztatták le. Ő eredetileg csupán egy hetilapot szeretett volna kiadni, „Békési Hírlap” címen. (Ez tudósításokat közölt volna a forradalomról, később pedig „főleg helyi jellegű problémákkal foglalkozott volna. Pártatlanul kellett volna müködnie.” - vallotta az 1957. május 16-i kihallgatáson. ${ }^{86}$ ) Bár a forradalom napjaiban például Békéscsabán, Gyulán és Battonyán is megjelentek forradalmi lapok, Márton a tervéhez nem tudta megnyerni a helyi forradalmi bizottságot. Ennek ellenére a lapcsinálási tervével még november 4. után sem hagyott fel, végül azonban úgy döntött, hogy - jobb híján - röplap-terjesztésbe fog. Mártont azzal is megvádolták, hogy október 25-én, majd pedig november 16-án kommunista-, illetve kormányellenes jelszavakat firkált házfalakra. (A vádirat szerint ezeket: „Lakásokat a volt pártházból”, „Vége a 12 éves kommunista uralomnak”, és „Éljen a forradalom”.) Hiába védekezett a tárgyaláson azzal, hogy ez nem igaz és csak azért írta alá a kihallgatásáról készített jegyzőkönyvet, mert „súlyos testi fenyítésben” részesítették - ezt nem fogadta el bíróság. ${ }^{87}$ Pedig valóban nem ő követte el ezt a büncselekményt. 1957. április 6-án ugyanis a megyei bíróság Durkó Istvánt és a fiatalkorú Gyaraki Jánost azért ítélte fél évre, illetve négyhavi felfüggesztett börtönbüntetésre, mert december 11-én este különféle jelszavakat firkáltak egyes Csabai úti és Szarvasi úti házak falára. Az alábbi jelszavakat írták fel: „Magyarország magyar haza, minden ruszki menjen haza”, „Le a kommunizmussal”, „Ma ecsettel, holnap fegyverrel". 88

Juhász György és társai ellen sem elsősorban a forradalom alatti tevékenységük miatt indult eljárás (amiatt is indíthattak volna, mert többen nemzetőrök voltak), hanem a november 4. utáni

„kulák” volt, vagy 1945 elött csendőr, esetleg „horthysta” katonatiszt, az ítélet meghozatalakor ezt súlyosbító körülményként vették figyelembe.

${ }^{84}$ Meg kell jegyeznünk, hogy ebben az időben az volt az általános gyakorlat, hogy másodfokon nem hogy enyhítettek volna, hanem inkább súlyosbítottak az ítéleten.

${ }^{85}$ Lásd az 1957. április 18-i ítéletet. (MNL BML, Békés Megyei Bíróság, büntetőügyek, XXV. 10.c. fond, B.553/1957. 7-11.)

${ }^{86}$ MNL BML, Békés Megyei Bíróság, büntetőügyek, Márton László és társai aktája, XXV. 10.c fond, B.374/1957. 35 .

${ }^{87}$ Lásd az 1957. június 27-i ítéletet. (Közli Vincze 2016b. 316-319.)

${ }^{88}$ Az 1957. április 6-i ítélet. MNL BML, Békés Megyei Bíróság, büntetöügyek, Durkó István és társa aktája, XXV. 10.c fond, B.131/1957. 7. (Jelen dolgozat szerzőjének édesanyja ezeket a feliratokat látta a szomszéd házfalakon...) 
tetteik miatt. A Juhász nevével fémjelzett fegyveres szervezkedést utólag az egyik legjelentősebbnek, a hatalomra legveszélyesebbnek ítélte a Békés megyei Rendőr-fökapitányság. Az 1960. március 8-i jelentésük szerint „ezt az ügyet március 9-én számoltuk fel”89 - ami biztosan nem igaz, ugyanis a még 1957. február 22-én internált Juhászt „csak” április 8-án vették őrizetbe, és aznap hallgatták ki először.

A szervezkedésre a „Virágos János” fedőnéven jelento hálózati személy hívta fel a politikai rendőrség figyelmét. 1957. február 13-i, egyik ${ }^{90}$ jelentésében az alábbiakat közölte a tartótisztjével, Csendes Ferenc hadnaggyal: „Az ellenforradalom után tudomásomra jutott, hogy Békés község hez tartozó II. és VII. k. Diter elnevezésü külterületen egyes személyek szervezkednek ujabb ellenforradalmi tevékenységre. [...] Amikor Békésen járok mindig beszoktam menni Rácz Nándor cipész mühelyébe. Ahol mindig ott találom Vezsenyi Lászlót, Szabó Gábor volt nemzetőröket. Feltünt, hogy igen sok fiatal jár Ráczhoz. Ha bementem mindig politikai vita folyt. Állandóan kérdezgették, hogy mit tudok. Ők közölték a külföldi híreket. Feltűnt, hogy a fenti személyek mindig ott vannak. Majd egy hete annak, hogy bent jártam a városban, és a vésztői vasúton találkoztam Szabó Gáborral. Amikor elmondta hogy Vezsenyi László Diteri lakos szervezi az egész Ditert és csak két géppisztolyuk van. Nyíltan hangoztatták, hogy tavasszal újra kezdődik az egész ellenforradalom". ${ }^{91}$

Az ügynökjelentés nyomán megkezdődtek az előzetes letartóztatások. Benkovics Sándor ${ }^{92}$ hadnagy már 1957. március 16-án részletes jelentést írt az ügyről: „Rácz Nándor 10-12 főből álló fegyveres csoportot szervezett 1956. november 4-e után, a csoport tagjai Rácz Nándor cipész mühelyében jártak össze megbeszélésekre, és külföldi rádió adásait hallgatni. A csoport decemberig három esetben készített ellenséges tartalmú röpcédulákat, és azt szét szórták. A röpcédula készítésében Rácz Nándor, Juhász György, Berc[z]i Gábor és Szabó István személyek vettek részt. A röpcédula szórásban és készítésében résztvevő személyeken kívül részt vettek Szabó Gábor, Nagy László, Kovács Zoltán, Kozma Imre, Kozma Ferenc, Berczi Gábor, Kozma Gábor és Kiss János személyek." 93 Márciustól májusig folytak a letartóztatások, végül összesen huszonhárom személy ellen emeltek vádat. (Kozma Gábort később valamiért nem tartóztatták le, Kozma Imre pedig még idejében „disszidált”, vagyis Jugoszlávián keresztül nyugatra szökött.)

A szervezkedés szellemi irányítója Zahorán Pál tanító és Rácz Nándor voltak, a csoport vezetőjének azonban még a nyomozati szakban a volt csendőrt, Juhász Györgyöt tették meg.

A vádlottak több csoportra oszthatók. Egy részüket azért ítélték el, mert a „népi demokratikus államrend megdöntésére irányuló fegyveres szervezkedés” kezdeményezésének, vezetésének

${ }^{89}$ A BM Békésmegyei Rendőrfőkapitányság 203-647/1960. sz. „Szigorúan titkos!” jelzésű jelentése a „belsőreakció elleni harc értékeléséről”. MNL BML, Békési Fióklevéltár, MSZMP-archívum, 1. fond, 14. fondcsoport, 9. örzési egység, 43.

90 Az aznapi, másik jelentését közli Vincze 2016b. 344-347.

91 ÁBTL, „Virágos János” munkadossziéja, 3.1.2. M-15320, 22.

92 Benkovics Sándor - akárcsak az 1956 végén ujjászervezett kádári politikai rendőrség tagjainak döntő többsége - ávós múlttal rendelkezett: az '50-es évek elején az ÁVH Csongrád megyei Főosztályán volt vizsgáló, részt vett egyebek mellett a Fehér Gárda megyei csoportosulásának „felgöngyölítésében”. A forradalom alatti tevékenységéről nem lehet tudni semmit (valószínűleg ő is átszökött Jugoszláviába, mint oly sok szegedi ávós). 1957 elején az égető káderhiány pótlására Szegedről időlegesen áthelyezték Békéscsabára, az ottani Politikai Nyomozó Osztályra. Mintegy három hónapig lehetett ott, mert 1957 májusa után nincs nyoma Békéscsabán. Lásd BÁLINT 2014. 39-40.

${ }^{93}$ VINCZE 2016b. 160-161. A csoporttól összesen kettő géppisztolyt, kettő hadipuskát, hét pisztolyt, tíz kézigránátot és nagy mennyiségü lőszert foglaltak le. 
vagy előmozdításának bűntettében találták bűnösnek. Egy részük „egyszerü” fegyverrejtegető ${ }^{94}$ volt, míg mások a „feljelentési kötelezettség elmulasztása” miatt lettek elítélve. ${ }^{95}$ A huszonhárom vádlott közül hatot már első fokon fölmentettek, bizonyítékok hiányában. Érthetetlen módon a másodfokú ítéletben az a fiatal nő, aki az írógépén sokszorosította a röplapokat, megúszta felfüggesztett börtönbüntetéssel.

A Rácz-Zahorán-féle fegyveres szervezkedés kapcsán ki kell térni egy érdekességre. Ök ugyanis azt hangoztatták, hogy „Maléter nagyobb létszámú fegyveres csoporttal a Bakonyban van és a tavasz folyamán újrakezdik 1956. október 23.-t”, ezért csatlakozni akartak „Maléter csapatához” ${ }^{96}$ Egyrészt nyilvánvaló, hogy Rácz György és Zahorán Pál a Szabad Európa Rádió magyar adásából nem értesültek arról, hogy Malétert és társait a szovjetek még 1956. november 3-án őrizetbe vették Tökölön, tehát semmiképp sem mehetett „mintegy 18.000 főnyi emberével” a Bakonyba, mint ahogy ezt Kozma Imre vizionálta... ${ }^{97}$ Másrészt a szervezkedést az 1957 tavaszán az országban elterjedt/elterjesztett „MUK”-mozgalom ${ }^{98}$ inspirálta.

Mint említettük, huszonhárom vádlottat állítottak a bíróság elé, közülük azonban hat személyt bizonyítékok hiányában fölmentettek. Azt, hogy ez miként volt lehetséges, a XIII. rendű, ugyancsak fölmentett vádlott, Vezsenyi László operatív dossziéjában található ügynökjelentésekből tudhatja meg az utókor.

Vezsenyi tevékeny tagja volt a szervezkedésnek. 1957. március 9-én „hálózati adatok alapján”, vagyis a „Virágos János” fedőnevü ügynök jelentése alapján fegyver és lőszerrejtegetés gyanújával elözetes letartóztatásba helyezték. Kezdettől fogva következetesen tagadta, hogy rejtegetne fegyvert és lőszert, ugyanis bár a letartóztatásakor a zsebében találtak 25-30 töltényt, de ezek nem kerültek be a házkutatási jegyzőkönyvbe, mivel Ivocska Pál rendőr hadnagy, aki régóta jó viszonyban volt vele, egyszerűen zsebre vágta a bűnjeleket. ${ }^{99}$ Ennek következtében a rendőrségnek csak az egyik terhelt vallomása állt a rendelkezésére, de utólag azzal sem tudtak mit kezdeni. ${ }^{100}$

A kihallgatásai során csupán annyit volt hajlandó - legalábbis eleinte - elismerni, hogy tagja volt a szervezkedésnek, és személyesen négy személyt szervezett be: Farkas Istvánt, Szabó Mátyást, Herpai Andrást és Futaki Mátyást. (Farkast nem vádolták meg, Szabót és Herpait pedig fölmentették.) Vezsenyi a nyomozati szakaszban tett vallomásait később visszavonta. Ennek okáról az egyik hálózati személynek, „Bánhegyi Róbert”-nek 1957 őszén annyit árult el, hogy „a

94 A megyében összesen negyvenkét személy ellen indítottak eljárást fegyver, lőszer és robbanóanyag rejtegetése miatt.

95 Lásd az 1957. augusztus 29-i ítéletet. (Közli Vincze 2016b. 174-210.)

96 VInCZE, 2016b 160-161. és ÁBTL, Juhász György és társai vizsgálati dossziéja: 3.1.9. V-144931., 69.

97 Lásd az 1957. augusztus 29-i ítéletben (VIncze 2016b. 190.). Ezt a legendát Maléter Pál felesége, Gyenes Judit a Szabad Európa Rádió magyar adásában hallotta. Lásd Magyar Nemzet, 2016. október 22., 27. („Hány évig várt Jákob Ráhelra? Maléter Pál feleségének egyetlen bűne a férje iránti ragaszkodás volt.”)

98 MUK = „Márciusban újrakezdjük”. Állítólag a forradalmárok által 1957 elejétől terjesztett jelszó. A kutatás jelenlegi állapotában nem lehet eldönteni, hogy ez a kádári állambiztonság által kiprovokált mozgalom volt, vagy valóban „ötvenhatosok” által kezdeményezett akció, amelyre „menet közben” „rátelepedett” az állambiztonság. Lásd KrahulCsán 2007.

99 Mindezt utólag kifecsegte „Virágos János”-nak. (ÁBTL, Vezsenyi László operatív dossziéja, 3.1.5 O-14978/17., 82-83.) A szorgos ügynök aljasságát mi sem mutatja jobban, mintsem hogy Vezsenyiből több alkalommal úgy szedte ki a bizalmas információkat, hogy előtte direkt leitatta.

100 Szabó Gábor a tárgyaláson kijelentette, hogy egyáltalán nem tett olyan vallomást, miszerint tudott arról, Vezsenyi rendelkezik fegyverrel és lőszerrel, a meghamisított jegyzőkönyvet pedig csak „kényszer hatása alatt” írta alá. (Lásd az elsőfokú ítéletben. Vincze 2016b. 207.) 
szabadulását kizárólag dr. Csicsely Mihálynak ${ }^{101}$ köszönheti."102 A következő évben, 1958 májusában azonban azt is elfecsegte „Virágos János”-nak, „az volt a szerencséje, hogy mielőtt Gyulán az ügyészi kihallgatás megtörtént volna, egy napra összezárták őket [a vádlott-társai egy részével] és összebeszélték a dolgot. Aki pedig külön volt, azok a mellettük lévő zárkában voltak, de azokkal úgy érintkeztek, hogy valami vízvezető cső van a zárkában, és azon keresztül beszélték meg, hogy ki mit mondjon. Egyébbként, aki a vallomásokat irányította, az egy szarvasi ügyvéd volt, Csicsely György $^{103}$. Ez az ember heteken keresztül oktatta őket, hogy ki mit mondjon, legfőbb hazudni."104 Egy másik, szintén ráállított spiclinek, a „Palotás Lajos”105 fedőnevű informátornak azt is kikotyogta, hogy „az ügyészi kihallgatása során változtatta meg vallomását, aminek eredményeként szabadult. Mint megjegyezte, ha bármikor is visszakerülne a főosztályra, mindent vállalna, mert azt úgyis megváltoztathatja az ügyészségen."106

Tehát az történt, hogy egyfelől a börtönőrök hanyagsága miatt a vádlottak egy részét öszszezárták, lehetővé téve az összebeszélést. Ráadásul Vezsenyiékkel együtt raboskodott egy, az ötvenes évek politikai pereiben tapasztalatokat szerzett, ugyancsak letartóztatott ügyvéd, aki fölvilágosította őket arról, hogy az ügyészi kihallgatás során nyugodtan visszavonhatják a korábbi vallomásaikat, csak az új vallomásaikat előzőleg egyeztessék egymás között. Ennek köszönhetö, hogy néhányukat fölmentették. (A történethez annyit azért érdemes hozzá tenni, hogy Vezsenyi Lászlót a fenti információk birtokában egészen 1969-ig figyeltették...)

Dolgozatunk végén röviden érdemes kitérni F. Szőke Gábor esetére. Ö azért kerülte el a felelősségre vonást, mert a családjával még idejében kiszökött nyugatra. Erről azonban - úgy tünik - az állambiztonsági szervek nem értesültek idejében. Pedig Szatmári István már az 1957. szeptember 11-i tárgyalásán azt vallotta, hogy tudomása szerint F. Szőke „disszidált”. Az állambiztonság emberei azonban meg voltak győződve arról, hogy még az országban bujkál. Nagy Gábor VB titkár 1958. január 30-i följelentését ${ }^{107}$ követően tavaszán kísérletet tettek az elfogására. Csendes Ferenc a Békésmegyei Rendőrfőkapitányság Politikai Nyomozó Osztály Békés Járási Kirendeltségének főhadnagya még aznap elrendelte az országos körözést. Azt gyanította, hogy az „ellenforradalmár” a kazincbarcikai rokonánál bujkál. Május 5-én Csendes főhadnagy kidolgozott egy „kombinációt”108 az elfogására. Erre azonban nem került, nem kerülhetett sor.

101 Dr. Csicsely Mihály (Szarvas, 1900-1981). Eredetileg földrajz-természetrajz szakos tanári diplomával rendelkezett, de később pályát módosítva beiratkozott a miskolci jogakadémiára, majd annak elvégzése után, 1937-ben Szarvason ügyvédi irodát nyitott. Aktív tagja lett az FKGP helyi szervezetének. Az ötvenes években több „kulákper”-ben vállalta el a védelmet. 1956-ban tagja volt a forradalmi tanácsnak és részt vett az FKGP újjászervezésében. 1957. február 22-én letartóztatták, majd december 6-án a Szarvasi György és társai per II. rendű vádlottjaként „a népi demokratikus államrend megdöntésére irányuló szervezkedés” büntettében való részvétel miatt első fokon nyolc év, majd másodfokon tíz börtönre ítélték. 1963 márciusában amnesztiával szabadult. Lásd ERdmann 2009. 319-332.

102 ÁBTL, Vezsenyi László operatív dossziéja, 3.1.5 O-14978/17., 77.

${ }^{103}$ Helyesen: Mihály.

104 ÁBTL, Vezsenyi László operatív dossziéja, 3.1.5 O-14978/17., 80.

105 „Palotás Lajos” eredeti neve Pankotai László, aki szintén részt vett a forradalomban, nemzetőr volt, de a felelősségre vonást megúszta, cserébe vállalta a „spicli” szerepét.

106 ÁBTL, Vezsenyi László operatív dossziéja, 3.1.5 O-14978/17., 84.

107 A följelentésében Nagy Gábor azt írta, hogy „1957. október 31-én láttam Békésen, amikor feleségével együtt a Köröstarcsa felé induló autóbuszra szálltak fel.”ÁBTL, F. Szőke Gábor operatív dossziéja, 3.1.5 O-9825, 25.

108 „Tervszerü operatív intézkedések egyidejü vagy sorozatos, egymás utáni alkalmazása egy, minőségileg új operatív helyzet elérése céljából. - A kombinációban egy vagy több titkos nyomozati (operatív) eszköz kerül alkalmazásra, hogy egymás hatásfokát növeljék. - Tartozéka: a természetes vagy a mesterséges operatív helyzet, a szükség szerinti legenda, az engedélyezett javaslat és a biztositási terv." In Állambiztonsági értelmezö kéziszótár. Budapest, 1980. 109. 
Csendes Ferenc főhadnagy 1958. szeptember 2-án azzal zárta le a dossziéját, hogy F. Szőke Gábor a családjával még januárban Ausztriába „disszidált”... ${ }^{109}$

Az internáló táborba került békésiek pontos számát - egyelőre - ugyanúgy nem lehet meghatározni, mint azt, hogy hányan kerültek börtönbe. A megyében csak 1957-ben több mint 400 politikai ügyben indult eljárás, ez az összes ügynek mintegy $70 \%$-át tette ki. ${ }^{110} \mathrm{~A}$ már korábban hivatkozott 1960 -as jelentés ${ }^{111}$ szerint összesen 485 személyt internáltak, Erdmann Gyula nyugalmazott gyulai levéltár-igazgató számításai szerint pedig mintegy hétszáz bírósági ítélet született 1956 ürügyén. ${ }^{112}$ Békéssel kapcsolatban is elmondható az, hogy „az elítéltek zöme munkás, iparos, földműves, kisparaszt, valamint értelmiségi volt."113

Az eddigi kutatások alapján úgy tünik, „csak” negyvenkét békési személyről lehet biztosan állítani, hogy letöltendő börtönbüntetésre ítélték. Szerencsére halálos ítélet vagy életfogytiglani ítélet nem született.

A megtorlásnak azonban ennek ellenére van egy békési halálos áldozata: a mezőberényi születésű, de 1956-ban a családjával Békésen élő Onofrei Károly. Öt 1957. március 17-én, amikor a budapesti munkahelyéről haza érkezett, a békési vasútállomáson lefogták, majd nyoma veszett. A békési „pufajkások” (vagy a helyi politikai rendőrök) két nappal később agyonverték. (Feltehetően csupán azért ölték meg, mert tagja volt a fövárosi közlekedési vállalat, a Beszkárt munkástanácsának.) Egy korabeli feljegyzés szerint március 19-én hunyt el. ${ }^{114}$ Élt harminckét évet...

Sáfár Gyula megállapítása Békésre is igaz: „Az elítéltek 1960-ban, majd 1963-ban szabadultak, de a bünhődésnek ezzel nem volt vége, sokan eredeti szakmájukhoz nem térhettek vissza, csak segédmunkásként tudtak elhelyezkedni. Ráadásul a börtönévek alatt a megtorlás az elítéltek családját is elérte, házastársukat elküldték a munkahelyükről, gyermekeik iskoláztatása megnehezült. Az 1956 után megtorlás évtizedekig súlyos árnyéként vetült nemcsak a volt elítéltekre, hanem az egész társadalomra."115

\section{FELHASZNÁLT IRODALOM}

BÁLINT LÁszló (2014): A kommunista párt öklei. Államvédelmi és állambiztonsági tisztek Szegeden és Csongrád megyében 1944-1990. Budapest, Kárpátia Stúdió.

BÉKÉsi MÁrTon LÁszLó (1994a): Azok a békési októberi napok... (1. rész: Néma tüntetés a szobornál, zajos lincshangulat a Bérházban) In Békési Újság 1994. október 21. 2.

BÉKÉsi MÁRTON LÁszLó (1994b): Békési fiatalok fegyveres szervezkedése 1956 őszén. In Békési Ujjág 1994. november 18. 7.

Bíró Friderika-Für Lajos (2013): Búcsú a parasztságtól. Első kötet: történelmi esszé. Budapest, 2013. Kairosz Kiadó - Szabadtéri Néprajzi Múzeum

109 ÁBTL, F. Szőke Gábor operatív dossziéja, 3.1.5 O-9825, 97.

110 SÁFÁR 2016.

${ }^{111}$ MNL BML, Békési Fióklevéltár, MSZMP-archívum, 1. fond, 14. fondcsoport, 9.őrzési egység, a BM Békésmegyei Rendőrfőkapitányság 203-647/1960. sz. jelentése a „belsőreakció elleni harc értékeléséről”. 41.

112 ERdMann 2006. 43.

113 SÁFÁR 2016.

114 FeKete 2006. 336-340. (A szerző szerint egy bizonyos „B. kapitány” volt Onofrei Károly gyilkosa, aki megérte a rendszer bukását.)

115 SÁFÁR 2016. 
Bokodi-Oláh Gergely (2014): Nemzet örség - 1956. Pázmány Péter Katolikus Egyetem, 2014. Doktori disszertáció. https://btk.ppke.hu/uploads/articles/7429/file/Bokodi-Ol\%C3\%A1h\%20Gergely_ disszert\%C3\%A1ci\%C3\%B3.pdf (Hozzáférés: 2016. 10. 06.)

Domonkos LÁszLó (1990): Magyar Sámsonok. (Paraszti ellenállás 1951-1955). H. n. Szegedi Nyomda.

ERDÉsz ÁdÁm (2017): A forradalom fordulópontjai. A részvétel és a támogatottság intenzitása egy alföldi városban, Gyulán. In Forradalom közelnézetböl. Az 1956-os forradalom és szabadságharc vidéki eseményei. (Szerk.: MikLós Péter). Hódmezővásárhely. 55-68.

Erdmann Gyula (1992): Begyüjtés, beszolgáltatás Magyarországon 1945-1956. Békéscsaba, Tevan Nyomda. Erdmann Gyula (2006): Békés megye 1956-ban. Források. I. kötet. Gyula, Békés Megyei Levéltár.

Erdmann Gyula (2009): Békés megye 1956-ban. Források. III/2. kötet. Gyula, Békés Megyei Levéltár.

Farkas Csaba (2006): Hatalomváltás Csongrád megyében 1956-ban. In Aetas 21. évf. 1. sz. 100-108.

FeKete PÁl (2003): Az utolsó szó jogán. Elsüllyedt világ - Békéscsaba, 1956. Budapest, Püski Kiadó.

FeKete PÁL (2006): Cseppek a tengerböl. Békés megye mártírjai és áldozatai a második világháború alatt és után. Budapest, Püski Kiadó.

Filep Tibor (1990): Politikai megtorlás és restauráció Hajdú-Biharban, 1956-57. In A Hajdú-Bihar Megyei Levéltár Évkönyve. Debrecen. 139-152.

KÁvÁsI Klára (1991): Kuláklista. Budapest, Agóra Könyv- és Lapkiadó.

Krahulcsán Zsolt (2007): MUK és HUKUK. In Betekintő, 2007. 2. sz. http://www.betekinto.hu/en/ node/105 (Hozzáférés: 2016. 09. 16.)

LőCsei PÁl (1999): Békéscsaba tizenkét napja a forradalomban. In STANDEisky Éva - RAiner M. János (szerk.): Évkönyv VII. (Magyarország a jelenkorban.) Budapest, 1956-os Intézet. 282-300.

Miklós PÉTer (2016): Szikra, láng, hamu. Az 1956-os magyar forradalom és szabadságharc Csongrád megyei emlékezete. Szeged, Csongrád Megyei Önkormányzat.

Mucsi ANDrÁs - VincZe GÁbor (2013): Nagy Ferenc és Nagy Imre államminisztere: B. Szabó István, a békési kisgazda politikus (1893-1976). Békés, Jantyik Mátyás Múzeum.

ORgovánYi István (2013): A Magyar Ellenállási Mozgalom. Röpcédulázás Békéssámson községben az ötvenes években. In Betekintő 7. évf. 4. sz.http://www.betekinto.hu/2013_4_orgovanyi (Hozzáférés: 2016. 09. 10.)

Ö. KovÁcs József (2012): A paraszti társadalom felszámolása a kommunista diktatúrában. A vidéki Magyarország politikai társadalomtörténete 1945-1965. Budapest, Korall.

ÖZe SÁNDOR - ÖZE Sándorné (2012): Sárréti Sasok. Nemzeti ellenállási mozgalom Kelet-Magyarországon 1948-1953. Budapest, Kárpátia Kiadó.

SÁFÁr GYula (2016): Az 1956 utáni megtorlás Békés megyében. In Bárka 2016. 5. sz. http://www.barkaonline. hu/esszek-tanulmanyok/5527-az-lundefined5undefined-utani-megtorlas-bekes-megyeben (Hozzáférés: 2017. 03. 10.)

Somlai Katalin (2003): Békés megye. In Szakolczai Attila - Á. VARga László (szerk.): A vidékforradalma, 1956. Budapest, 1956-os Intézet - Budapest Főváros Levéltára. 92-120.

Szuromi Tímea - Jenei Éva (2004): '56-os olvasókönyv. Válogatás a korabeli békéscsabai sajtóból. Békéscsaba, a Békéscsabai Ifjúsági Ház kiadása.

UNGVÁRY KRISZTIÁN (2013): Kisgazdapárti politikusokés azállambiztonság. In Ungváry Krisztián (szerk.): Búvópatakok. A jobboldal és az állambiztonság 1945-1989. Budapest, 1956-os Intézet Alapítvány Jaffa Kiadó. 81-142.

VINCZE GÁвоR (2013): Hruscsovék döntettek: Nagy Imre. (Amikor Moszkvában döntötték el, ki legyen a magyar helytartó.) In Történelemportál 2. évf. 2. sz. 18-21.

Vincze GÁBor (2016a): Kérdőjelek. A dél-alföldi Fehér Gárda Mozgalom első korszaka. In Historia est lux veritatis. Szakály Sándor köszöntése 60. születésnapján. III. kötet. Budapest, Veritas Történetkutató Intézet. 115-132.

VincZe GÁвоR (2016b): A békétlen Békés. Forradalom és megtorlás Békésen. Békés, Jantyik Mátyás Múzeum. Zinner Tibor (2001): A kádári megtorlás rendszere. Budapest, Hamvas Intézet. 